\title{
Depositional environment, ichnological features and oxygenation of Permian to earliest Triassic marine sediments in central Spitsbergen, Svalbard
}

\author{
Alfred Uchman, ${ }^{1}$ Nils-Martin Hanken, ${ }^{2,3}$ Jesper Kresten Nielsen, ${ }^{4}$ Sten-Andreas Grundvåg ${ }^{2,5}$ \& \\ Stefan Piasecki ${ }^{6}$ \\ 1 Institute of Geological Sciences, Jagiellonian University, Oleandry Str. 2a, PL-30-063, Kraków, Poland \\ 2 Department of Geology, University of Tromsø - the Arctic University of Norway, Dramsveien 201, NO-9037 Tromsø, Norway \\ ${ }^{3}$ Department of Geosciences, University of Oslo, PO Box 1047 Blindern, NO-0316 Oslo, Norway (current address) \\ ${ }^{4}$ MOL Norge AS, Trelastgata 3, NO-0191 Oslo, Norway \\ ${ }^{5}$ Department of Arctic Geology, The University Centre in Svalbard, PO Box 156, NO-9171 Longyearbyen, Norway \\ ${ }^{6}$ Geological Museum, Natural History Museum of Denmark, Øster Voldgade 5-7, DK-1350 Copenhagen K, Denmark
}

\section{Keywords}

Trace fossils; Permian-Triassic boundary; palynology; spiculites; trace elements; anoxicity.

\section{Correspondence}

Alfred Uchman, Jagiellonian University, Institute of Geological Sciences, Oleandry Str. 2a, PL-30-063, Kraków, Poland.

E-mail: alfred.uchman@uj.edu.pl

\begin{abstract}
Late Early Permian-lowermost Triassic carbonate, siliceous (spiculites) and clastic marine sediments in the Marmierfjellet area (Isfjorden, central Spitsbergen) contain a relatively diverse and abundant trace fossil assemblage providing important information about the depositional processes. The Vøringen Member (Late Artinskian-Kungurian) of the Kapp Starostin Formation (Late Artinskian-? Changhsingian) contains trace fossils (Nereites, Phycosiphon, Zoophycos and Arenicolites - common in tempestites) typical of the proximalarchetypal Cruziana ichnofacies, which indicates lower shoreface. Nereites, Phycosiphon and Zoophycos, accompanied by other rare trace fossils, characterize the Svenskegga and Hovtinden members of the Kapp Starostin Formation. They are interpreted as the distal Cruziana ichnofacies, possibly transitional to the Zoophycos ichnofacies typical of the lower offshore zone. However, the sporadic occurrences of Arenicolites and Macaronichnus can point to episodic shallowing to upper offshore-lower shoreface. The lowest part of the Triassic Vikinghøgda Formation (Induan-Olenekian) contains a very low-diverse ichnoassemblage composed of a few simple and branched forms ascribed to the impoverished Cruziana ichnofacies (lower to upper offshore environment), which is attributed to the early recovery stage after the Permian-Triassic extinction. The trace fossils and loss of primary sedimentary structures caused by intense bioturbation throughout most of the section point to generally oxygenated pore waters on the sea floor. However, some horizons, especially laminated black shales, display reduced or no bioturbational activity. These horizons also show high $\mathrm{V} /(\mathrm{V}+\mathrm{Ni})$ ratios, which indicate oxygen-depleted sediments with periods of anoxic conditions. A remarkable black shale unit deposited under anoxic and sulphidic conditions occurs at the Permian-Triassic transition.
\end{abstract}

To access the supplementary material for this article, please see the supplementary files under Article Tools, online.
The northern margin of the supercontinent Pangaea was situated at about $20^{\circ} \mathrm{N}$ during the Late Carboniferous and drifted northwards to $45^{\circ} \mathrm{N}$ in the Late Permian
(Stemmerik 2000; Golonka 2011). This shift in palaeolatitudes caused a marked change predominantly from warm-water carbonates to cool-water carbonates and 
spiculites encountered in Arctic Canada, North Greenland, Svalbard and the Barents Sea (Beauchamp \& Desrochers 1997; Stemmerik 1997, 2000; Stemmerik \& Worsley 2005; Blomeier et al. 2011; Grundvåg et al. 2013; Nielsen et al. 2013). The latest Permian and Early Triassic were associated with a temperature rise (Georgieva et al. 2011; Sun et al. 2012) and are mostly characterized by siliciclastic sediments with few macrofossils at Svalbard (Mørk et al. 1999).

At the end of the Permian, life was nearly completely wiped out by an environmental catastrophe of a magnitude never seen before or since (e.g., Erwin 1993, 2006). The mass extinction annihilated about $95 \%$ of the marine skeletal organisms and $80 \%$ of land animals (e.g., Knoll et al. 2007; Payne et al. 2007; Sahney \& Benton 2008). Shen, Crowley et al. (2011) dated the extinction peak to just before $252.28 \pm 0.08$ Mya, a time interval very close to the Changhsingian (Permian)-Induan (Triassic) boundary (Gradstein et al. 2012). Both marine and terrestrial ecosystems collapsed suddenly. Shen, Crowley et al. (2011) give evidence for an extinction interval of less than $200 \mathrm{Kya}$; Burgess et al. (2014) indicate that the ecosystems collapsed in only $60 \mathrm{Kya}$. The most widely accepted causes of the Permian-Triassic mass extinction have been summarized by Payne \& Clapham (2012), Chen et al. (2013) and others. Episodic shoaling of anoxic water onto shallower water areas (Kajiwara et al. 1994; Wignall \& Twitchett 1996; Algeo et al. 2008; Nielsen et al. 2010; Shen, Farquhar et al. 2011; Schoepfer et al. 2013; Wei et al. 2015) may have had a major impact on the mass extinction.

So far, investigations of the Permian-Triassic extinction have mostly concentrated upon body fossils (e.g., Jin et al. 2000; Twitchett et al. 2001; Knoll 2004), but much less is known about the trace fossils. Therefore, we have concentrated upon describing the trace fossils from a well-exposed late Early Permian to earliest Triassic marine sequence at Marmierfjellet, Svalbard. In addition to describing the trace fossils and their stratigraphic range, we have also carried out trace element analysis to achieve a better understanding of the redox fluctuations of the bottom water during deposition and the relationships between the facies development and ichnofauna (for material and methods see Supplementary File 1).

\section{Geological setting}

On Spitsbergen, upper Palaeozoic rocks can be traced as a narrow belt from Sørkapp in the south along the west coast to Brøggerhalvøya in the north (Fig. 1).
However, the largest and most continuous exposures occur in central Spitsbergen. Cutbill \& Challinor (1965) erected a lithostratigraphic framework for the Upper Carboniferous and Permian strata, which has been only slightly modified by later workers. For an overview, see Dallmann et al. (1999), who also give an overview of the Triassic lithostratigraphy. In this paper, we follow the revised lower Triassic stratigraphy given by Mørk et al. (1999).

The sections studied in this work are situated at the north side of Marmierfjellet (Fig. 2), where the uppermost part of the Gipshuken Formation (SakmarianArtinskian), the Kapp Starostin Formation (late Artinskian?Changhsingian) and the lowermost part of the Vikinghøgda Formation (Induan-Olenekian) are well exposed. The Kapp Starostin Formation, which is the main focus of this study, accumulated in a marine basin that had several depocentres separated by structural highs. There was probably a continental area to the west of Svalbard and the basin was shallowing to the south and to the northeast where the Kapp Starostin Formation is significantly thinner and onlaps the Sørkapp-Hornsund High and the Nordaustlandet platform, respectively (Steel \& Worsley 1984; Worsley et al. 1986; Harland et al. 1997; Ehrenberg et al. 2001; Fig. 3). As shown by the fence diagram in Fig. 3, the Kapp Starostin Formation is characterized by a complex interfingering of lithofacies and has a maximum thickness near the entrance of Isfjorden. The formation is up to $500 \mathrm{~m}$ thick in the deeper part of the basin and significantly thinner towards the basin margins (e.g., the Sørkapp-Hornsund High), indicating a considerable rate of subsidence and down-warping along major lineaments (Steel \& Worsley 1984; Worsley et al. 1986). Several depositional models have been proposed for the Kapp Starostin Formation (Małkowski \& Hoffman 1979; Szaniawski \& Małkowski 1979; Małkowski 1982, 1988; Fredriksen 1988; Henriksen 1988; Ezaki et al. 1994; Nakrem 1994; Olempska \& Błaszyk 1996; Ehrenberg et al. 2001; Grundvåg 2008; Blomeier et al. 2011; Dustira et al. 2013). There is a general agreement that the bioclastic Vøringen Member was deposited in a near-shore to shallow-water setting during rising sea level, being replaced upwards by open marine shelf facies. The succeeding part of the Kapp Starostin Formation is dominated by chert/cherty shale and spiculites. There is also a general high glauconite content, which was interpreted by Ezaki et al. (1994) to indicate low sedimentation rates, possibly forming condensed deposits. The spiculites can be divided into light- and dark-coloured varieties. Ehrenberg et al. (2001) suggested that the light-coloured 


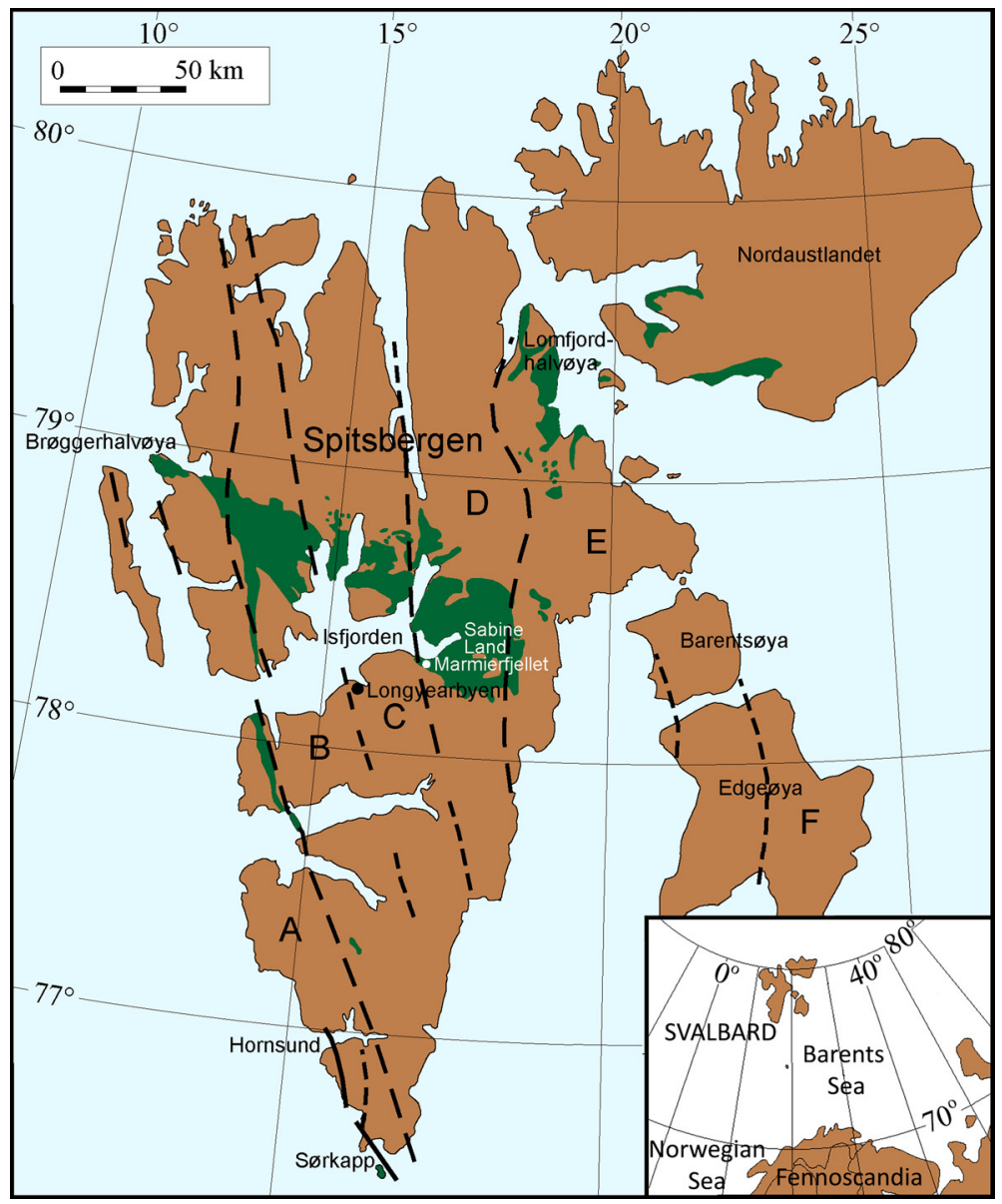

Fig. 1 Map of Svalbard with exposures of Carboniferous-Permian rocks in green. Structural elements: A: Sørkapp-Hornsund High; B: Central Trough (St. Johnsfjorden Trough); C: Nordfjorden High; D: Billefjorden Trough; E-F: Ny Friesland Trough. Major fault lineaments are also shown. Modified from Nakrem et al. (1992).

variety were formed in well oxygenated, quiet water below the storm wave base while the dark spiculites were deposited in deeper water. The glauconitic sandstone in the top of the Kapp Starostin Formation represents nearshore facies, indicating an Upper Permian regressive phase occurring in proximity to basin margins and palaeo-highs (e.g., Worsley et al. 1986; Ezaki et al. 1994; Ehrenberg et al. 2001). This part of the sequence also contains a meagre fauna of disarticulated lingulids.

The underlying Gipshuken Formation in the western part of Svalbard is characterized by stacked tidal flats and sabkha sequences dominated by interbedded dolomites and evaporites - gypsum and/or anhydrite (Fig. 4). The top of the Gipshuken Formation is characterized by an erosional surface reflecting a hiatus of tens of millions of years. The sediments on the ravinement surface normally consist of a $2-5 \mathrm{~cm}$ thick dark brown to black shaly bed overlain by a transgressive barrier sequence referred to as the Vøringen Member (Cutbill \& Challinor 1965), comprising the lower part of the Kapp Starostin Formation (Fig. 4). This unit is up to $40 \mathrm{~m}$ thick (Dallmann et al. 1999) and is dominated by bioclastic carbonate banks with a rich fauna of brachiopods, bryozoans and crinoids (Nakrem et al. 1992; Ezaki et al. 1994; Nielsen et al. 2013). The Vøringen Member represents shoreface deposits, which were regarded by Worsley et al. (1986) to represent a carbonate barrier sequence that migrated across the restricted marine platform and sabkha environments of the underlying Gipshuken Formation.

The Kapp Starostin Formation comprises several members (Fig. 4; Dallmann et al. 1999). In our study area, it is only possible to correlate the lowermost part of the Kapp Starostin Formation with the Vøringen Member as defined by Cutbill \& Challinor (1965). The scantiness of skeletal fossils in the upper part has caused some discrepancy regarding the age of the uppermost part of 


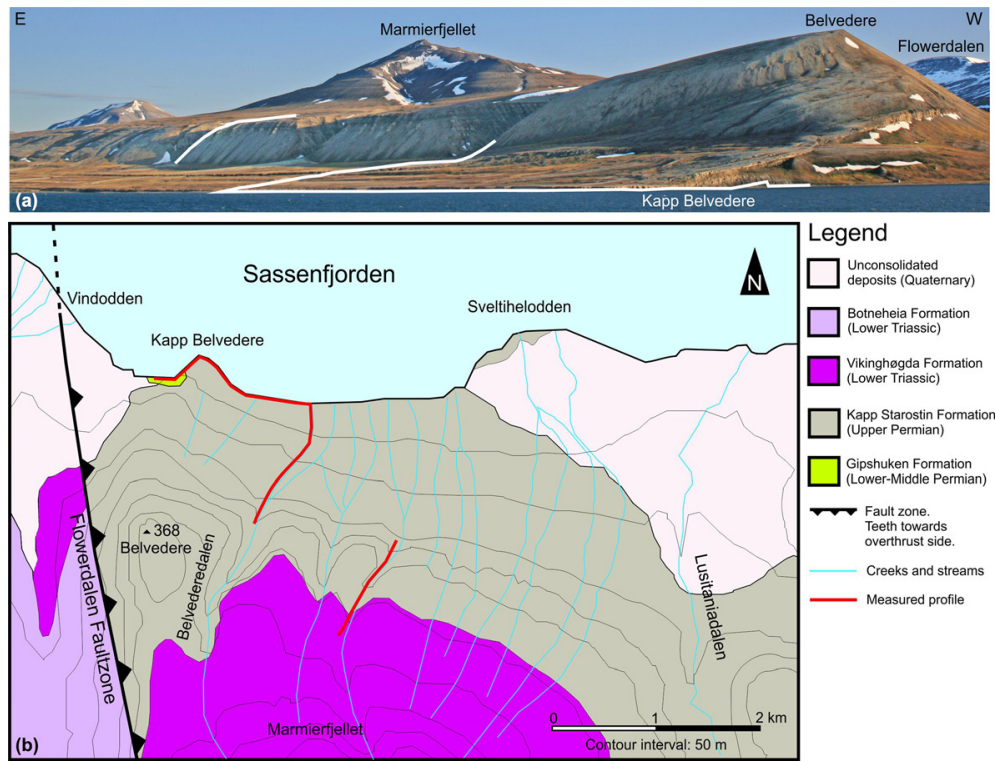

Fig. 2 (a) Picture taken from Sassenfjorden looking south towards the outcrops. White lines indicate the location of the measured profiles. (b) Geological map showing the profile lines. Modified from Major et al. (1992).

the Kapp Starostin Formation, leading Mangerud (1994) to conclude that palynomorphs are the best fossil group for correlation in this part of the sequence. The overlying informal members, Svenskegga and Hovtinden members, have therefore previously only been defined in the type area at outer Isfjorden (Cutbill \& Challinor 1965). Their stratigraphic relation to other sections of the Kapp Starostin Formation is unclear because of discrepancies in these definitions and local facies development (Dallmann et al. 1999).

The Permian-Triassic boundary at Svalbard has traditionally been placed on the top of the Kapp Starostin Formation, where it is an abrupt change from sandy facies or spiculites to black shales of the Sassendalen Group (Mørk et al. 1982; Gruszczyński et al. 1989; Mørk et al. 1989; Mørk et al. 1999), producing a distinct recess in the cliff line. Biostratigraphic correlation of different skeletal materials indicates the presence of a hiatus between the Permian and Triassic (sensu Blomeier et al. 2011), but preliminary magnetostratigraphic data from central Spitsbergen by Hounslow et al. (1996) suggest that the Permian-Triassic transition is complete, occurring around the formation boundary. Palynological studies by Mangerud \& Konieczny (1993) in western Spitsbergen also supported the view that there was a continuous sequence, characterized by a very slow sedimentation rate across the Permian-Triassic boundary. This is consistent with work by Mørk et al. (1982), Steel \& Worsley (1984) and Małkowski et al. (1989) in the central part of the basin, revealing a conformable transition from the Kapp Starostin
Formation into the overlying Vikinghøgda Formation, although Mørk et al. (1989) suggested that the contact was an enigmatic, non-erosive submarine hiatus. According to Nakrem et al. (1992), this indicates a condensed Late Permian succession.

Wignall et al. (1998) attempted from modest organic carbon isotope data to define a continuous sedimentation across the Permian-Triassic boundary from the Kapp Starostin-Festningen section in the western Spitsbergen, and suggested that the actual boundary can be found in the basal metres of the Vikinghøgda Formation. On account of the lack of biostratigraphic control, the continuous sedimentation across the Permian-Triassic boundary was later questioned by Wignall et al. (2013). Using palynomorphs, Mørk et al. (1999) showed that the Permian-Triassic boundary was situated in the lower part of the Vikinghøgda Formation (within 1.7-4.7 m above the base). The presence of the fungal spore Tympanicsyta stoschiana in the basal part of the lower part of the Vikinghøgda Formation (Mangerud \& Konieczny 1993) is very similar to a distinct fungal spike described from the latest Permian strata in Tethyan sections (e.g., Visscher et al. 1996; Wignall \& Twitchett 1996). Wignall et al. (1998) took this as an indication that the PermianTriassic boundary occurs in the basal metres of the Vikinghøgda Formation. Biomagnetostratigraphy of the Permian-Triassic Arctic Boreal successions by Hounslow \& Nawrocki (2008) and Hounslow et al. (2008) shows that the Permian-Triassic boundary post-dates a pronounced palynofloral turnover and predates a short duration 

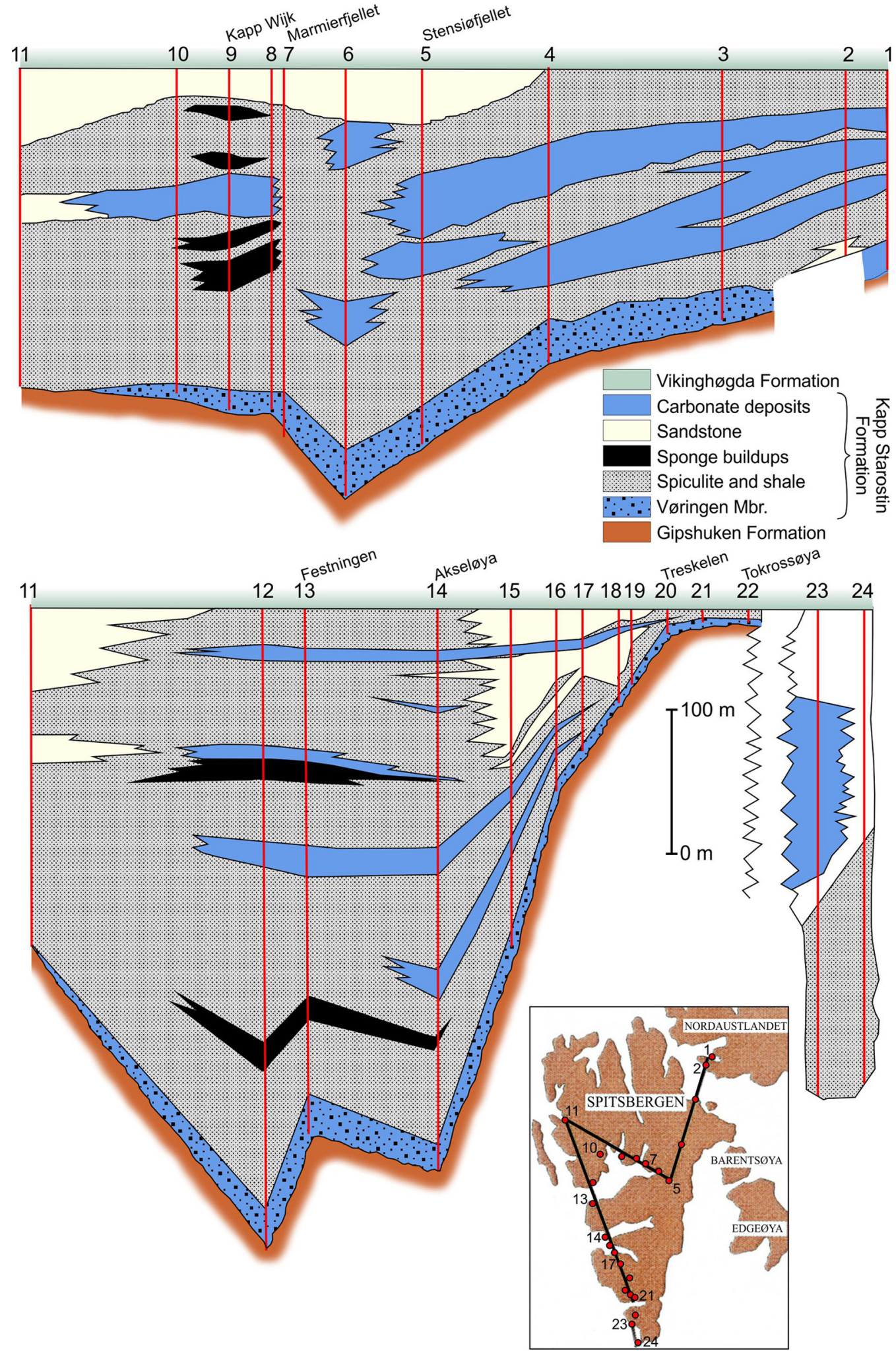

Fig. 3 Fence diagram showing thickness and lateral development of the main lithological units within the Kapp Starostin Formation. The abrupt change from sandy spiculitic facies to black organic shale has been used as a datum because this lithological change is easily seen in the field and is very close to the Permian-Triassic boundary. Modified from Worsley et al. (1986), Fredriksen (1988) and Henriksen (1988). 


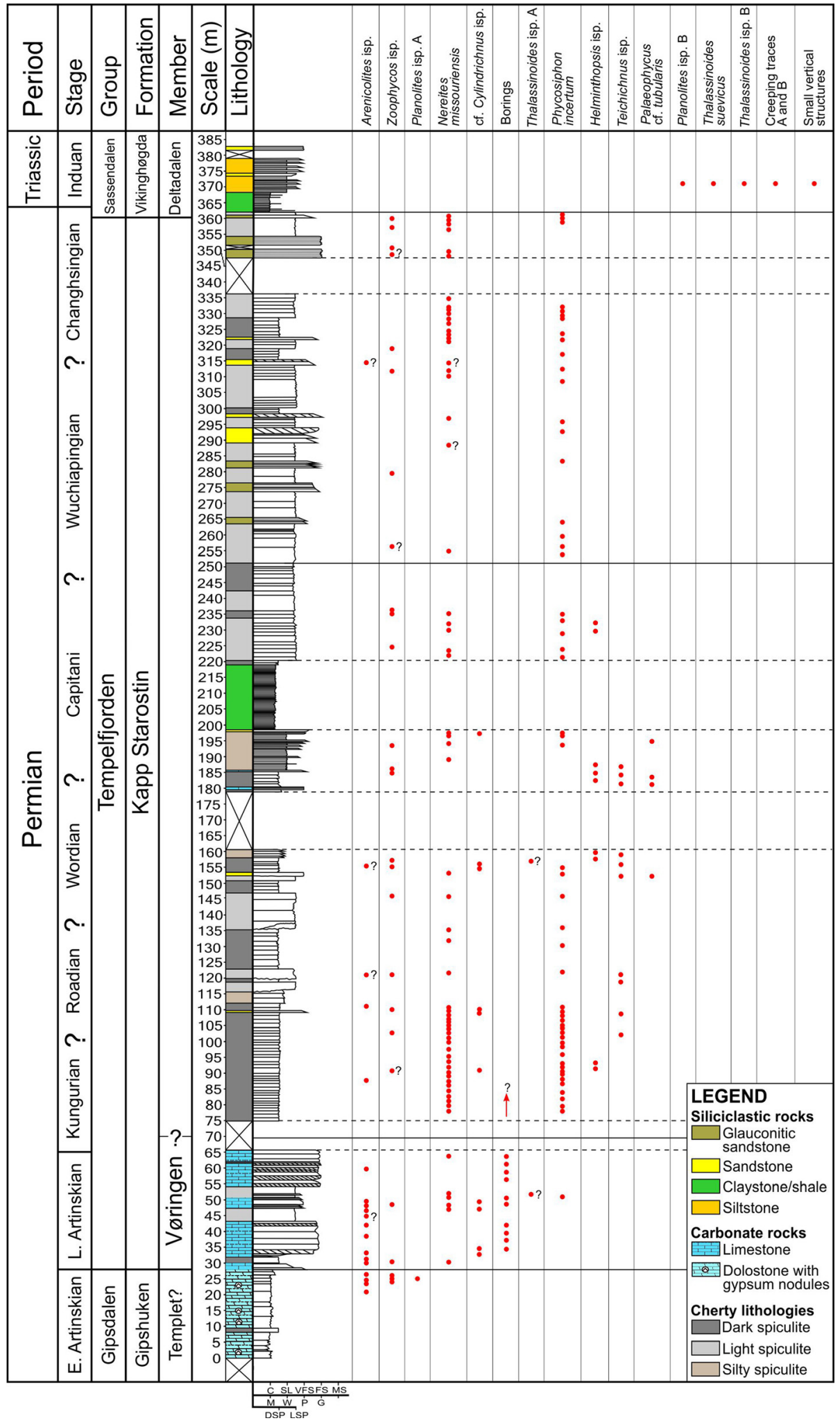

Fig. 4 Sedimentological log showing the vertical range of trace fossils, Marmierfjellet, central Spitsbergen. See text for discussion of the stratigraphy. The grain size of siliciclastic material and classification of the limestone deposits according to Dunham (1962) is shown along the X axis. Dark and light spiculites are abbreviated as DSP and LSP, respectively. 
reverse magnetozone. In Svalbard, the Permian-Triassic transition seems to be continuous in the central Spitsbergen, in the south and east there is a pronounced hiatus, while there is a submarine hiatus in the western Barents Sea (Mørk \& Mangerud 2013). Vigran et al. (2014) have recently introduced a formal palyno-stratigraphy from the uppermost Permian and Triassic in the northernmost Atlantic region, including Svalbard. They report the Permian-Triassic boundary in lowermost Vikinghøgda Formation of central Svalbard, based on sparse and poorly preserved sporomorphs and their zonation is applied to the present succession to identify the Permian-Triassic boundary.

\section{Previous investigations of Upper Permian and Lower Triassic trace fossils in Svalbard}

There are no systematic descriptions of the trace fossil fauna in the Kapp Starostin Formation. Brief investigations of Zoophycos assemblages on Akseløya on the west coast of Spitsbergen have been conducted by Bromley et al. (1989), Hanken et al. (1989) and Bromley \& Hanken (1992). The common occurrence of Zoophycos in the Kapp Starostin Formation has also been men-

Table 1 Trace fossils from the studied deposits.

Burrows

Arenicolites isp.; Fig. 5a, b, 11a?

Chondrites isp.; Fig. $5 \mathrm{c}$

cf. Cylindrichnus isp.; Fig. 5d, e, 7c

Helminthopsis isp.; Fig. 6a, b

Macaronichnus segregatis Clifton \& Thompson, 1978; Fig. 5f-h

Nereites missouriensis (Weller, 1889); Fig. 7a-f, 8f, 11a-d

Palaeophycus cf. tubularis Hall, 1847; Fig. 8d

Phycosiphon incertum Fischer-Ooster, 1858; Fig. 7b, d, 8a-c

Planolites isp. A and B; Fig. 8e, 10b

Teichichnus isp.; Fig. $8 f$

Thalassinoides suevicus (Rieth, 1932); Fig. 9a

Thalassinoides isp. A; Fig. 9b

?Thalassinoides isp. B; Fig. 9c, $\mathrm{f}$

Zoophycos isp.; Fig. 7c, 8c, 9d-g

Creeping traces $A$ and $B$; Fig. 10a-C

Small vertical structures; Fig. 10d

Borings

cf. Conchotrema isp. A; Fig. 12a, 13e

cf. Conchotrema isp. B; Fig. 12c, e, g, h

cf. Oichnus isp.; Fig. 13c

Palaeosabella prisca (McCoy, 1855); Fig. $12 f$

Pinaceocladichnus isp.; Fig. 12b

Rogerella isp.; Fig. 13a, b

?Talpina isp. A; Fig. 13d, f

?Talpina isp. B; Fig. 12d

Contorted tubes; Fig. $12 \mathrm{~h}$

Small galleries; Fig. 13b, c tioned by Dallmann et al. (1999: 117). Stemmerik $\delta$ Worsley (1995) pointed out that the spiculitic shales are dominated by Zoophycos, Thalassinoides, Chondrites and Phycosiphon, while Hüneke et al. (2001) pointed out that the spiculites are intensely bioturbated and dominated by Schaubcylindrichnus, Scalarituba, Thalassinoides and Chondrites. Lofek (2012) described the trace fossil fauna from the Kapp Starostin Formation at Akseløya and the Lower Triassic Vikinghøgda Formation at Mariaholmen, west Spitsbergen.

Wignall et al. (1998) investigated the distribution of ichnotaxa in the topmost Kapp Starostin Formation and Vikinghøgda (Vardebukta) Formation of the Kapp Starostin-Festningen coastal section. Apparently, the trace fossil assemblage in the spiculitic Kapp Starostin Formation contains only four ichnotaxa at this locality. There is an abrupt change at the base of the Vikinghøgda Formation, where Zoophycos, Diplocraterion and Chondrites disappear and Planolites is joined by small pyritized burrows in the Selanderneset Member (Lower Triassic). Trace fossil diversity gradually increases in the overlying Siksaken Member of the Vikinghøgda Formation. The trace fossil fauna crossing the Permian-Triassic transition in Lusitaniadalen from eastern Spitsbergen has also been described by Mørk et al. (1999) and Nabbefeld et al. (2010). Unlike the northern side of Marmierfjellet studied here, the upper Permian sandstone facies in Lusitaniadalen has a high ichnodiversity including amongst others Thalassinoides, Arenicolites, Skolithos and Palaeophycus.

\section{Palynology}

Six samples from the Permian-Triassic succession at the Marmierfjellet section were analysed for palynomorphs.

Two samples from a shale unit (198.9 and $218.0 \mathrm{~m}$ ) in the middle part of the Kapp Starostin Formation contain a typical Upper Permian, terrestrial spore-pollen flora dominated by abundant Vittatina and Protohaploxypinus together with other bisaccate pollen and relatively few trilete spores (e.g., Krauselisporites). The marine flora comprises abundant acritarchs referred to Micrhystridium, Reinoddendinium, Unellidinium and Veryhaccium. The samples are referred to spore and pollen zone B and acritarch zone 3 from the Upper Permian (Dorning et al. 1984), and to Krauselisporites spp. assemblage from the LowerUpper Permian (Artinskian-Capitanian) (Mangerud \& Konieczny 1993).

Four samples were analysed from the uppermost Kapp Starostin Formation to the lowermost Vikinghøgda Formation to locate the Permian-Triassic boundary in the studied succession. The recent palynological biozonation 

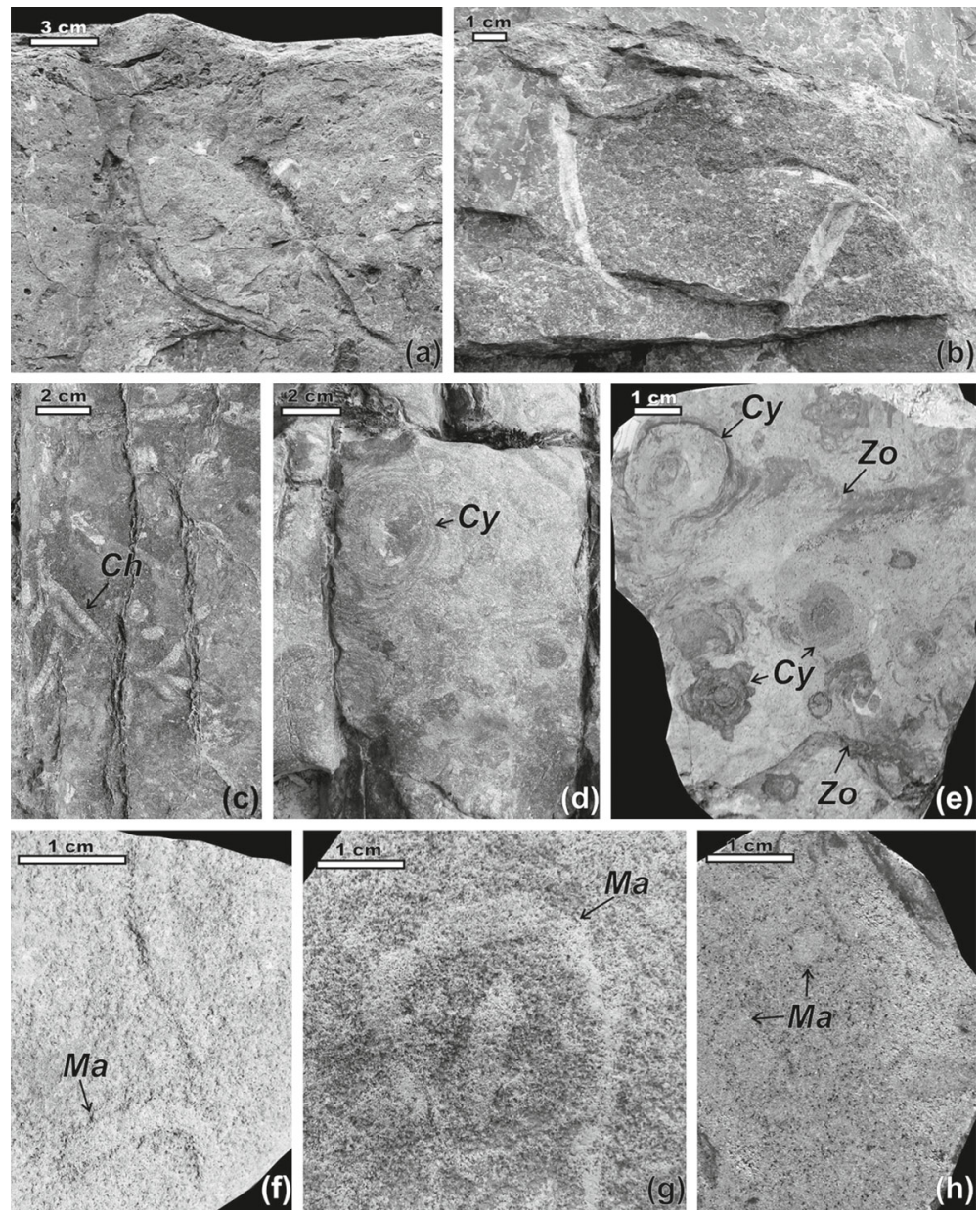

Fig. 5 Trace fossils of the Kapp Starostin Formation. (a), (b) Arenicolites isp. in vertical cross-section of sandstone beds from the lower part of the section (0-26 m). (c) Chondrites isp. (Ch) on the upper surface of a sandstone bed, ca. $120 \mathrm{~m}$ of the section. (d) Cf. Cylindrichnus isp. (Cy) on the upper surface of a sandstone bed, $120 \mathrm{~m}$ of the section. (e) Cf. Cylindrichnus isp. (Cy) and Zoophycos isp. (Zo) on the horizontal section of a bed, $120 \mathrm{~m}$ of the section, INGUJ207P2a. (f)-(h) Macaronichnus segregatis (Ma) in loose blocks. Cross-section in (h); (f) INGUJ207P18, (h) INGUJ207P13a.

by Vigran et al. (2014) erected for the northernmost Atlantic region, is applied to these samples. The Triassic samples contain strongly degraded spores and pollen, together with poorly preserved marine algae embedded in abundant and degraded organic matter; only sporomorphs with very characteristic morphology can be identified.

The sample from the uppermost Kapp Starostin Formation is distinctly different from the overlying samples in that the sporomorphs are associated only with abundant brown and black woody material. The three higher samples in the basal Vikinghøgda Formation are rich in very fine-grained organic material, partly in the form of microscopic coprolites. The composition of the organic matter suggests that the lower sample was deposited in a well-oxygenated environment, whereas the preservation of the delicate coprolite forms as well as the fine-grained organic debris in the three upper samplesmay indicate a low-energy environment with reduced oxygen content and consequently less degradation of the organic debris and little agitation of the settled debris.

Vigran et al. (2014) define three biostratigraphic zones at the Permian-Triassic transition and correlate the zones to the Permian-Triassic boundary. The Uvaesporites imperialis Composite Assemblage Zone (Changhsingian, uppermost Permian), the Reduviasporonites chalastrus C. A. Zone (Permian-Triassic transition) and the Proprisporites pocockii C. A. Zone (lower Induan, Triassic). The $U$. imperialis C. A. Zone is characterized by a total dominance of lycopod spores; for example, an acme of $U$. imperialis. The lower boundary of $R$. chalastrus C. A. Zone is defined by the first appearance datum of Lundbladispora obsoleta and the lower boundary of the $P$. pocockii C. A. Zone is defined by the first appearance datum of Densoisporites nejburgii. 

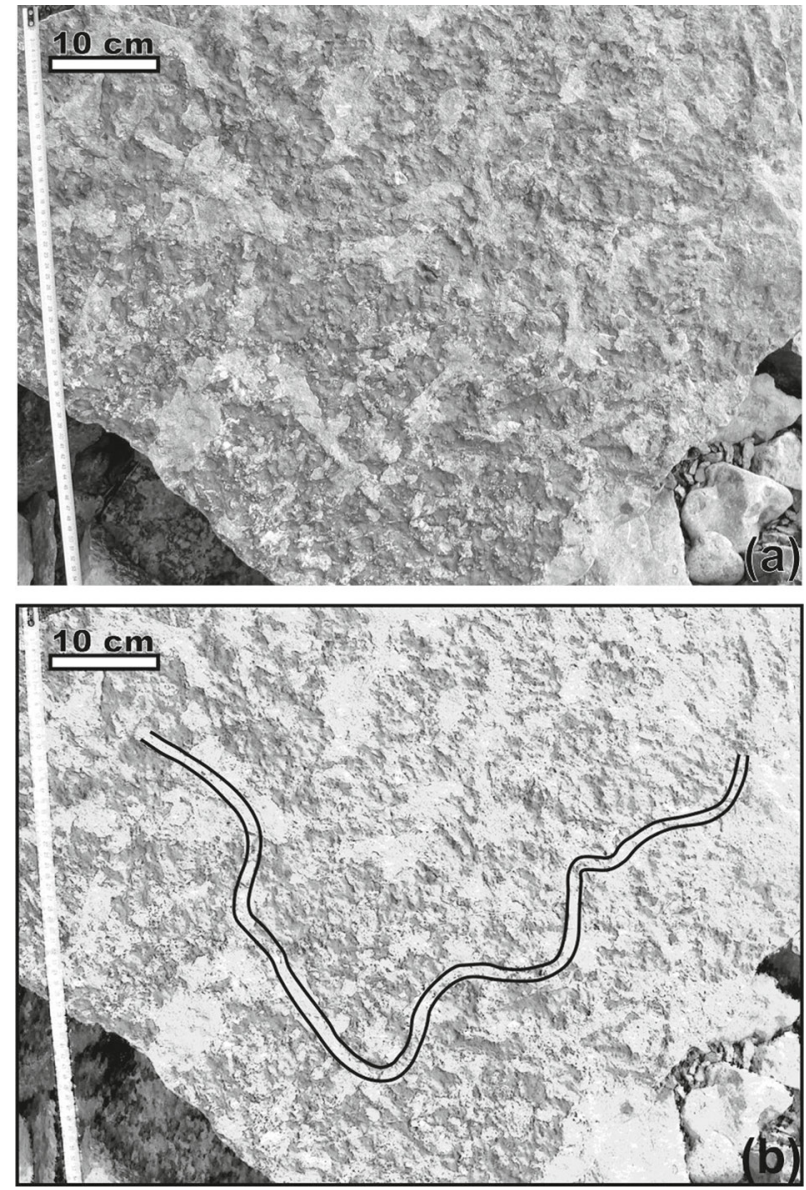

Fig. 6 Helminthopsis isp. on the lower surface of a sandstone bed from the lower part of the section. (a) View of the slab. (b) Drawing showing Helminthopsis isp.

In the present study, the lower sample contains a typical Upper Permian flora of abundant Vittatina, Protohaploxypinus and Krauselisporites in association with a diverse acritarch flora, for example, Cymatiosphaera, Reinoddedinium, Unellidinium and Veryhachium. Neither $U$. imperialis, nor $R$. chalastra or any L. obsoleta is recorded herein and the age is therefore considered Upper Permian.

The next higher sample is in the Vikinghøgda Formation ( $0.12 \mathrm{~m}$ above the base of the formation) and is dominated by the acritarch Micrhystridium, in association with a scanty sporomorph assemblage dominated by small Lunatisporites. Rare and degraded, cavate trilete spores, similar in shape and size to L. obsoleta as well as rare potential $R$. chalastra remains have been recovered from the sample. These vague data suggest affinity to the $R$. chalastra C. A. Zone (Vigran et al. 2014) embracing the Permian-Triassic boundary.

Two higher samples (363.10 and $374.70 \mathrm{~m}$; respectively 1.35 and $12.95 \mathrm{~m}$ above the basis of the Vikinghøgda
Formation) both contain a similar Micrhystridium and Lunatisporites assemblage but the presence of rare, possible $D$. neiburgii suggests affinity to the lower $P$. pocockii C. A. Zone. Slightly improved preservation in the upper sample reveals common Krauselisporites together with rare Maculatasporites, Proprisporites, Uvaesporites, Crustaesporites globosus, Vittatina and cavate/cingulate spores in tetrads. A minute unclassified alga occurs abundantly in the upper sample.

The Permian-Triassic boundary occurs therefore near the base of the Vikinghøgda Formation, probably in the lowest $12 \mathrm{~cm}$ but certainly lower than $1.11 \mathrm{~m}$ above the base.

\section{Trace fossils}

Trace fossils identified include 17 ichnotaxa of burrow and 10 ichnotaxa of borings (Table 1). For their systematic description see Supplementary File 2 and for methods of preparation of borings see Supplementary File 3.

\section{Geochemistry}

Generally, the Ni content of the shales ( $>1 \mathrm{~cm}$ thickness) ranges from about 4 to $200 \mathrm{ppm}$, with an average of about 42 ppm (not shown). The Ni content is obviously faciesdependent, as shown by enrichment in the thicker shale units. The $\mathrm{V}$ content ranges from 9 to $277 \mathrm{ppm}$, with an average value of about $108 \mathrm{ppm}$. The $\mathrm{V}$ content shows a similar facies dependence to that of the Ni content. However, a low Ni but high V content has been found for the thin-bedded shales intercalated with the dark spiculites in the lower part of the Svenskegga member. The highest contents of both $\mathrm{Ni}$ and $\mathrm{V}$ are found in the thinbedded shales interbedded with the dolostones of the Gipshuken Formation, the thick shale unit in the middle part of the Kapp Starostin Formation, and in most of the shales at the Permian-Triassic boundary.

The $\mathrm{V} /(\mathrm{V}+\mathrm{Ni})$ ratio of the investigated shales ranges from 0.35 to 0.94 with an average of 0.72 (Figs. 14, 15). Most of the shales represent lower dysoxic, anoxic to sulphidic bottom-water conditions (see also later). Note that the evidence from fauna and trace fossils in the interbedded deposits indicates that the anoxic and sulphidic conditions were usually short-lived and therefore punctuated by more oxic conditions.

\section{Discussion}

\section{Ichnofacies}

The trace fossil diversity in the Permian sediments is moderately low (Fig. 4). Only 12 ichnogenera are recognized, 

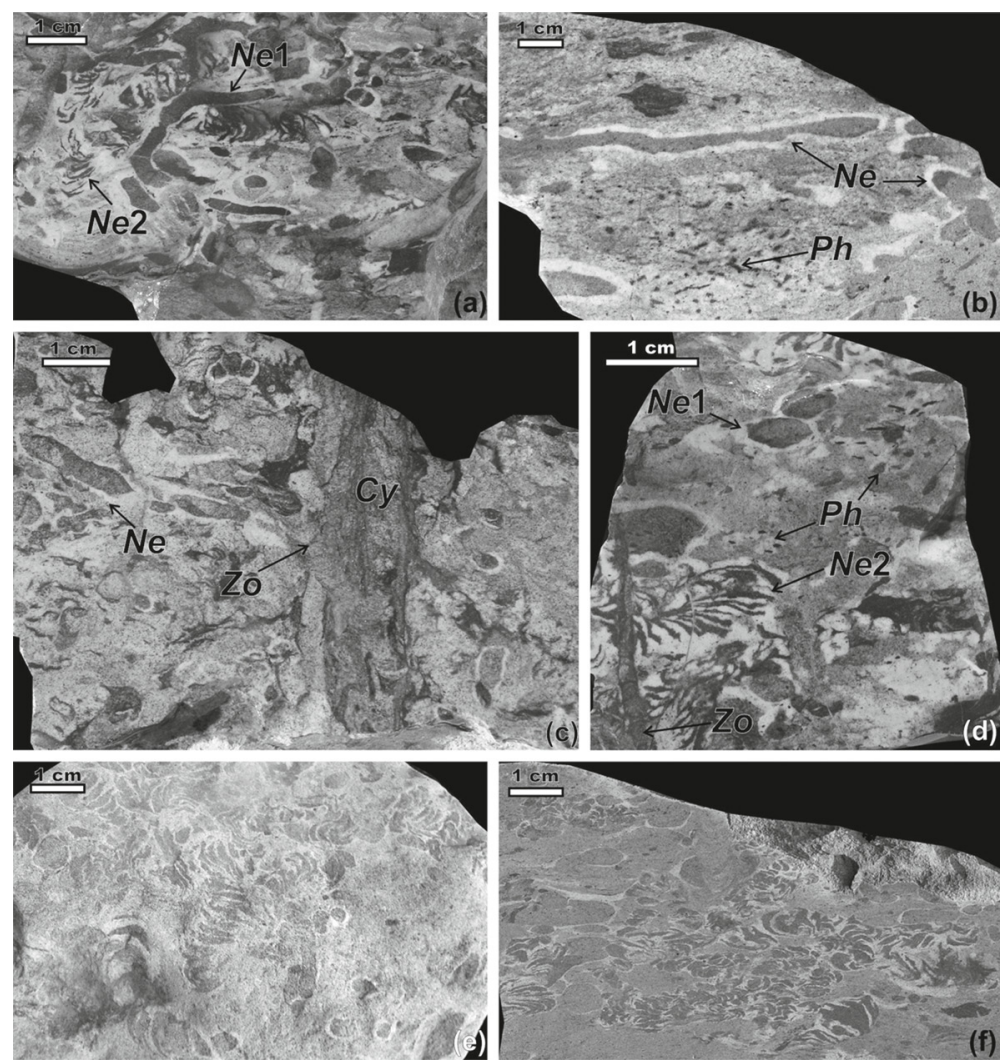

Fig. 7 Nereites missouriensis and other trace fossils from the Kapp Starostin Formation on (a)-(d), (f) polished slabs or (e) rough surfaces. (a) N. missouriensis seen as continuous ribbons (Ne1) or chains of scaliform menisci (Ne2), $56 \mathrm{~m}$ of the section, INGUJ207P6. (b) N. missouriensis (Ne) and Phycosiphon incertum (Ph), $318 \mathrm{~m}$ of the section, INGUJ207P3a. (c) N. missouriensis (Ne), Zoophycos isp. (Zo) and cf. Cylindrichnus isp. (Cy), $74.5 \mathrm{~m}$ of the section, INGUJ207P7. (d) N. missouriensis seen as continuous ribbons (Ne1) or chains of scaliform menisci (Ne2), Zoophycos isp. (Zo) and Phycosiphon incertum (Ph), $95 \mathrm{~m}$ of the section, INGUJ207P28. (e), (f) N. missouriensis, (e) $153 \mathrm{~m}$ of the section, (f) 305-306 $\mathrm{m}$ of the section, INGUJ207P10.

among which Nereites missouriensis, Phycosiphon incertum, Zoophycos isp. and Arenicolites are common. The other ichnotaxa are rare. The ichnoassemblage is dominated by pascichnia (Nereites, Phycosiphon) and fodinichnia (Zoophycos). Generally, they are typical of the Cruziana ichnofacies, which typically occurs in shoreface and offshore sediments (Fig. 16). However, the fine-grained sediments, where only Nereites, Phycosiphon and Zoophycos are present, can be considered as transitional to the Zoophycos ichnofacies (e.g., Frey \& Seilacher 1980; MacEachern et al. 2007), which represents deeper, commonly oxygendeficient environments.

The Cruziana ichnofacies, however, can be subdivided into proximal, archetypal and distal parts (Pemberton et al. 2001). The Vøringen Member is dominated by thick carbonate banks, some of which display hummocky cross-stratification or graded bedding. At least some of them can be interpreted as proximal tempestites. These sediments contain Nereites, Phycosiphon and Zoophycos, and commonly Arenicolites. This assemblage can be interpreted as the proximal-archetypal Cruziana ichnofacies, which is typical of lower shoreface (Pemberton et al. 2001). Arenicolites is common in storm beds (Frey \& Goldring 1992).

In the middle and upper part of the formation, Nereites, Phycosiphon and Zoophycos are rarely accompanied by other trace fossils. This assemblage can be interpreted as the distal Cruziana ichnofacies, maybe transitional to the Zoophycos ichnofacies. These ichnofacies indicate a lower offshore zone (Pemberton et al. 2001). The Zoophycos ichnofacies is problematic because Zoophycos generally occurs in shallow-water deposits in the Palaeozoic, but begins to occur in deeper waters since the Middle Jurassic (Bottjer et al. 1988; Olivero 2003). The Zoophycos ichnofacies refers mostly to Mesozoic and Cenozoic settings, after migration of the Zoophycos tracemaker to the deep sea. Therefore, even mass occurrence of Zoophycos in the Palaeozoic is not evidence of a palaeoenvironment deeper than the shelf. The sporadic occurrence of other trace fossils in some thin sandstone beds 

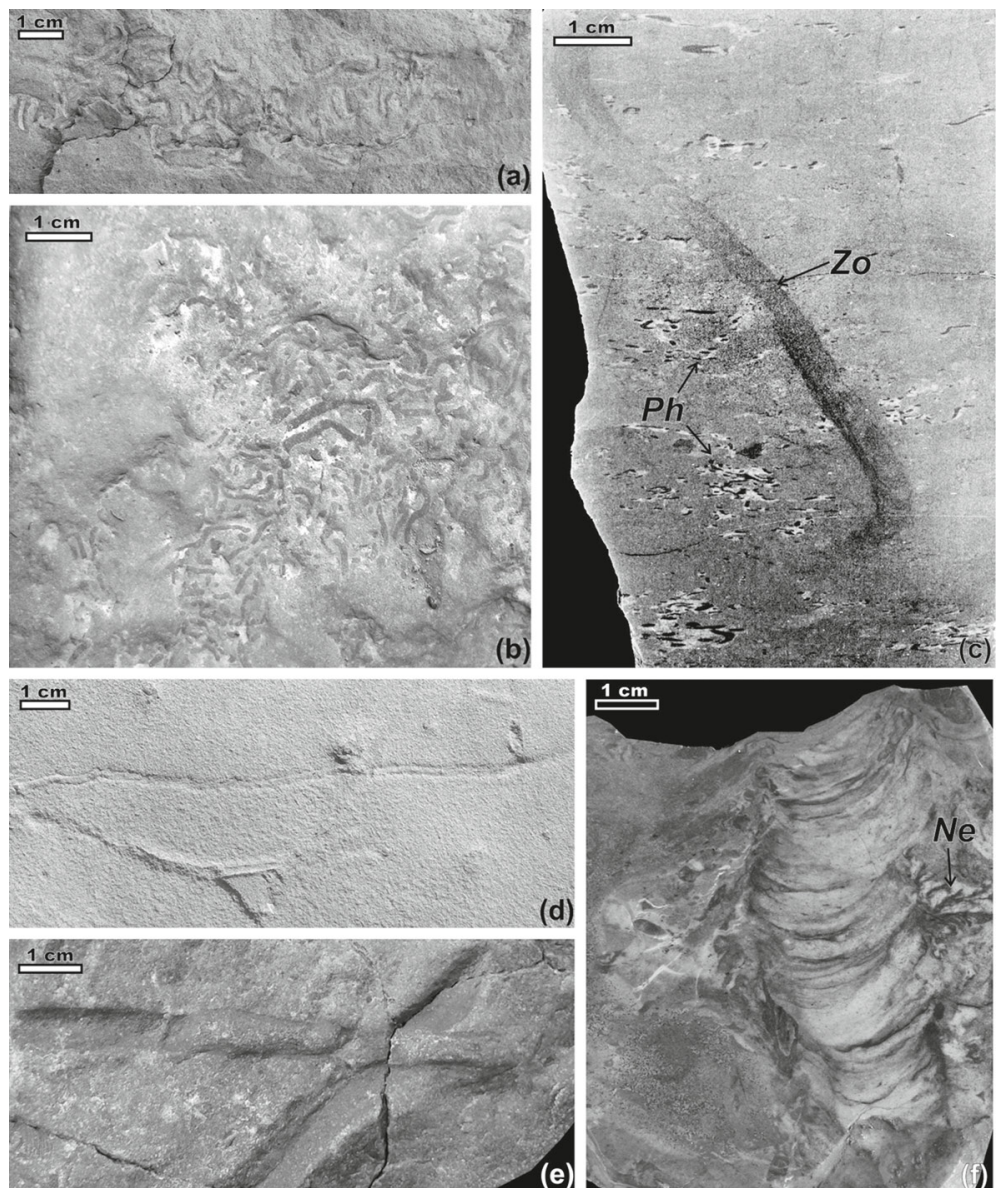

Fig. 8 Some spreite and simple trace fossils from (a)-(c), (d) the Triassic deposits, (e) the Gipsuken Formation and (f) the Kapp Starostin Formation. (a)-(b) Phycosiphon incertum on a rough bedding surface (a) 152-155 m of the section, (b) from a loose slab. (c) Phycosiphon incertum (Ph) and Zoophycos isp. (Zo) in vertical cross-section, $150 \mathrm{~m}$ of the section. (d) Palaeophycus cf. tubularis, bedding surface. (e) Planolites isp. A, bedding surface, lower part of the section (0-26 m). (f) Teichichnus isp. crossing N. missouriensis (Ne), $77 \mathrm{~m}$ of the section, INGUJ207P9.

(e.g., at 109, 153 and $315 \mathrm{~m}$ ), especially Arenicolites, can be interpreted as an occurrence of the archetypal Cruziana ichnofacies and upper offshore-lower shoreface deposits. Macaronichnus has been found at a level of $290 \mathrm{~m}$ in a small gorge situated about $200 \mathrm{~m}$ west of the main profile. This trace fossil is common in well-oxygenated shoreface and foreshore sands (Pemberton et al. 2001).

Some horizons of the Triassic siltstones contain a very low-diversity ichnoassemblage composed of a few simple and branched forms (Fig. 4). They can be ascribed to the impoverished Cruziana ichnofacies. The impoverishment was probably caused by anoxia and consequences of the Permian-Triassic global mass extinction. This ichnofacies, together with the presence of hummocky cross-stratified beds (e.g., Grundvåg 2008; Grundvåg et al. 2013), suggests a lower to upper offshore environment. The low diversity, small size, low complexity, low penetration depth and low degree of bioturbation are typical of Induan trace fossil assemblages in many parts of the world, as a consequence of the major Permian-Triassic event, in the first stage of recovery sensu Twitchett (2006; see also, e.g., Twitchett \& Wignall 1996; Chen et al. 2011; Chen et al. 2012; and references therein). However, very early advanced (late Griesbachian) recovery manifested by higher ichnodiversity is noted in tropic and boreal realms (Wignall et al. 1998; MacNaughton \& Zonneveld 2010; Hofmann et al. 2011). It seems that the ichnoassemblage investigated here represents times before this recovery interval. The interval probably corresponds to the lowest part of the Vardebukta Formation, which is bioturbated with small, sinuous and occasionally branched burrows situated below an about $50 \mathrm{~m}$ thick interval of anoxic sediments (Wignall \& Twitchett 1996).

An abundance of borings, as in the case of brachiopod shells from the Vøringen Member, is generally associated with a shallow, oxygenated marine environment; however, 

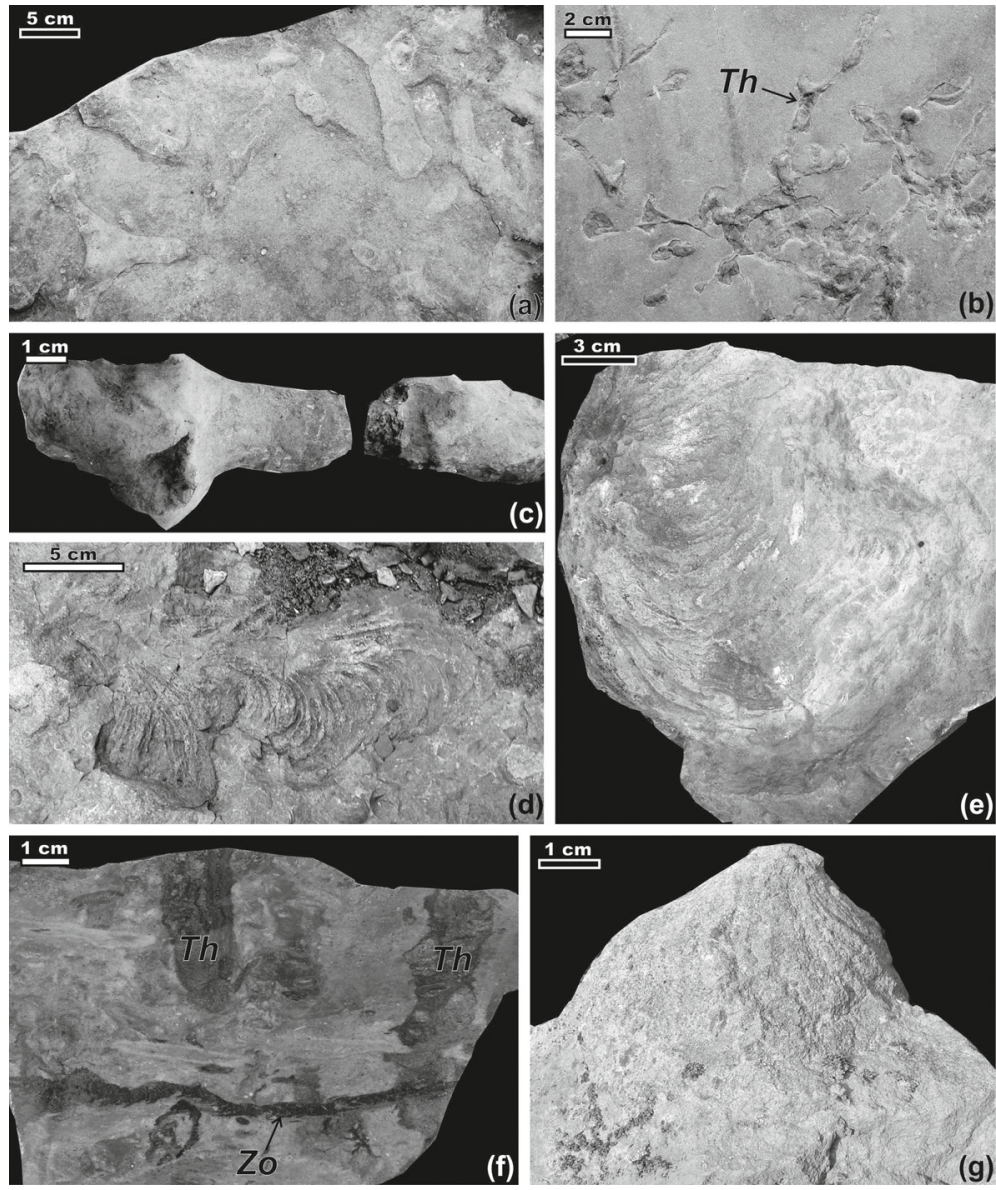

Fig. 9 Other trace fossils from (a) and (b) the Triassic deposits and (c)-(g) the Kapp Starostin Formation. (a) Thalassinoides suevicus, bedding surface. (b) Thalassinoides isp. A (Th), bedding surface. (c) ?Thalassinoides isp. B, fragments of filling, $121 \mathrm{~m}$ of the section, INGUJ207P22 (left) and INGUJ207P23 (right). (d)-(e) Zoophycos isp. on bedding surface, lower part of the section (10-26 m). (f) Zoophycos isp. (Zo) and ?Thalassinoides isp. B (Th), vertical section, $155.5 \mathrm{~m}$ of the section, INGUJ207P4a. (g) Steeply inclined spreite of Zoophycos isp., 273-276 m of the section.

individual borings, for example, Rogerella or Conchotrema, can occur in circumlittoral and bathyal Neogene settings (Bromley \& D'Alessandro 1990). Their production requires an exposition on the sea floor, probably no less than a few months, as can be speculated by comparison with recent experiments (Bromley \& Asgaard 1993).

\section{Oxygenation}

In the Gipshuken Formation, there are several thin shales interbedding dolostones containing evaporite nodules (Fig. 14). V/(V+Ni) ratios of the thin shale $(>1$ $\mathrm{cm}$ ) indicate that these laminated sediments were deposited in somewhat dysoxic to anoxic and sulphidic bottom-water conditions. The limited thickness of these thin shale beds indicates short duration of these hostile bottom conditions. Such conditions were most likely triggered by saline brines formed in a warm dry climate
(Stemmerik \& Worsley 2005), where dense saline waters contained less oxygen. In the uppermost part of the Gipshuken Formation, there is a significant trend toward lower $\mathrm{V} /(\mathrm{V}+\mathrm{Ni})$ values of the thin shales that subsequently turn to higher values. This reflects a change from sulphidic to anoxic and dysoxic conditions, and then back to anoxic and sulphidic conditions. When the dysoxic (and probably frequent oxic) conditions prevailed, the less stressed environment allowed the ichnotaxa Arenicolites isp., Zoophycos isp. and Planolites isp. A to develop (Figs. 4, 14).

In the overlying Vøringen Member, the ichnotaxa increase in number and also include abundant borings (Fig. 4) where productids and spiriferinids, together with other brachiopod taxa (terebratulids and rhynchonellids), often show the presence of bioerosion, indicating that the skeletal material was exposed for some time at the sea floor before final burial. 

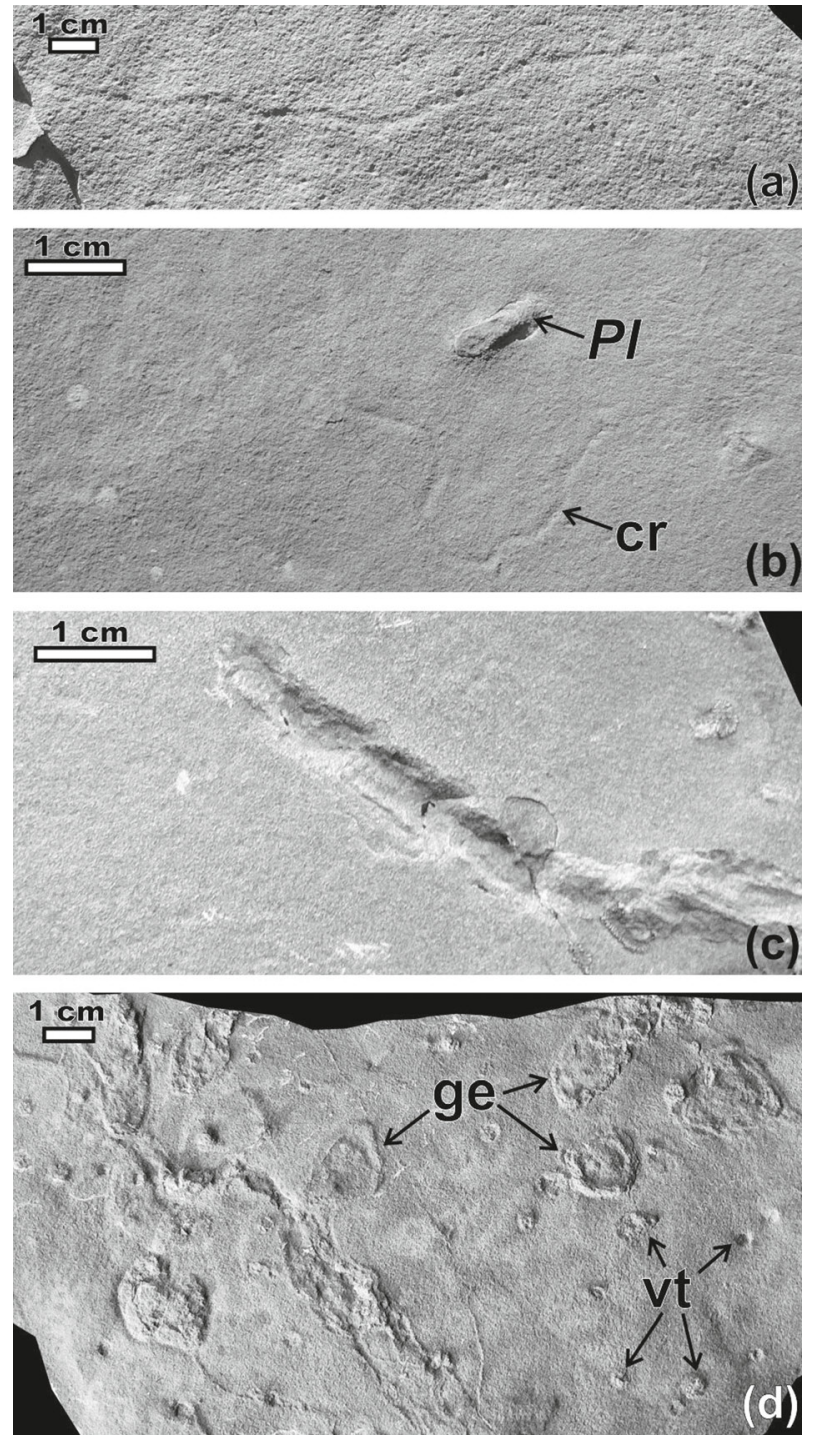

Fig. 10 Trace fossils from the Triassic on bedding surfaces. (a) Creeping trace A. (b) Creeping trace A (cr) and Planolites isp. (Pl). (c) Creeping trace B, INGUJ207P36. (d) Small vertical structures (vt) and probable gas escape structures (ge), $395.5 \mathrm{~m}$ of the section, INGUJ207P35.

The depositional conditions from the Gipshuken Formation to the Vøringen Member changed to a less stressed environment, where oxygen-richer waters became dominant. Only two thin shale units of a few $\mathrm{cm}$ in thickness are evidence of short-lived anoxic and sulphidic bottom-water conditions at levels $29.9 \mathrm{~m}$ and $44.5 \mathrm{~m}$ (Fig. 14) characterized by the absence of ichnotaxa.

The middle part of the formation is dominated by dark spiculites interbedded by light spiculites, silty spiculites and thin shales ( $>1 \mathrm{~cm}$ thickness). The very frequent occurrence of Nereites missouriensis and Phycosiphon incertum, among others, found in the spiculites indicates that oxygen-rich bottom waters existed dominantly, although frequently punctuated by short-lived anoxic (and perhaps sulphidic) conditions (Figs. 4, 14). The absence of silica sponges during deposition of the laminated sediments suggests that the fauna was intolerant to shoaling of oxygen-depleted deeper waters into the shallower water.

Anoxia in fine-grained sediments is manifested by fine, parallel lamination and the absence of trace fossils such as Nereites and Phycosiphon, which form within the substrate and use oxygen from pore water. The thick dark shale of the Svenskegga member (198.9-218 m) is not laminated, yet does not contain trace fossils (Fig. 4). The overall lack of lamination can be explained by very shallow bioturbation limited to water-saturated sediments, where burrowing does not cause the formation of trace fossils (e.g., Bromley 1996). The infrequent lowdiversity bryozoan fauna, the lack of trace fossils and the $\mathrm{V} /(\mathrm{Ni}+\mathrm{V})$ ratios show that anoxic conditions overall changed to dysoxic conditions throughout the thick shale unit (Fig. 14). An enrichment of sponges and brachiopods in the upper part of the thick shale unit confirms a transition toward more oxygenated bottomwater conditions.

The upper part of the formation is mostly bioturbated, with an almost continuous record of trace fossils, mostly Nereites and Phycosiphon (Fig. 4). This suggests oxygenated bottom waters during deposition of the Kapp Starostin Formation at the northern side of the Marmierfjellet. The situation is uncertain for some segments of the section, where primary features are strongly obliterated by diagenetic processes, mostly silicification (Fig. 9d). However, very short anoxic periods cannot be excluded. Laminated sediments deposited during such periods are too thin to be preserved after subsequent bioturbation during improvement of oxygenation. However, periods of anoxia are recorded as dark laminated shales $(>1 \mathrm{~cm}$ thick), where lack of infauna and the relatively high $\mathrm{V} /(\mathrm{V}+\mathrm{Ni})$ ratios indicate anoxic and sulphidic bottomwater conditions (Fig. 14).

At the Permian-Triassic transition, there is a significant change from Zoophycos isp., Nereites missouriensis and Phycosiphon incertum to no recorded trace fossils in the thick laminated dark shale unit (Fig. 4). As indicated by relatively high $\mathrm{V} /(\mathrm{V}+\mathrm{Ni})$ ratios, this may be related to anoxic and sulphidic bottom-water conditions recorded throughout the thick shale unit (Fig. 15). The anoxic bottom-water conditions existed prior to the PermianTriassic boundary, reported from East Greenland (Nielsen $\delta$ Shen 2004) and elsewhere. A more detailed biostratigraphic study than presented here is needed to unravel 

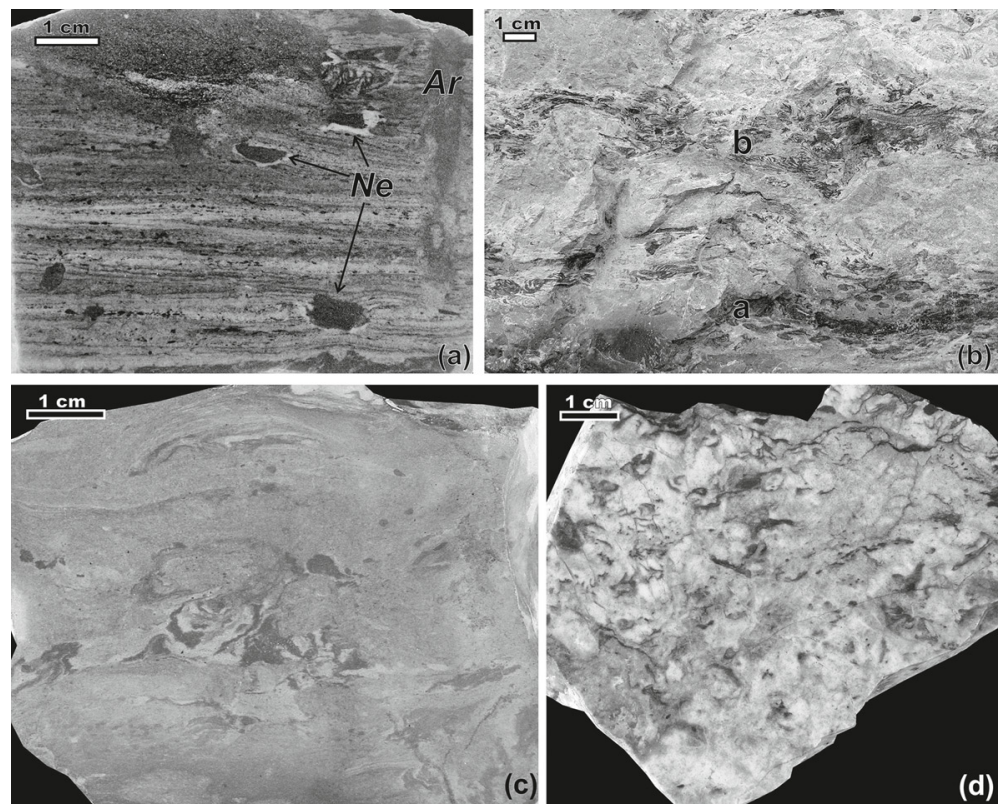

Fig. 11 Some ichnological features of the Kapp Starostin Formation. (a) Nereites missouriensis (Ne) and ?Arenicolites isp. (Ar) crossing primary cross lamination, $55 \mathrm{~m}$ of the section. (b) Two horizons (a, b) with abundant Nereites missouriensis, 200-220 m of the section. (c) Smeared Nereites missouriensis due to deformation in a very soft sediment, $349.8 \mathrm{~m}$ of the section, INGUJ207P12. (d) Obliterated Nereites missouriensis due to silicification, $102 \mathrm{~m}$ of the section, INGUJ207P25.
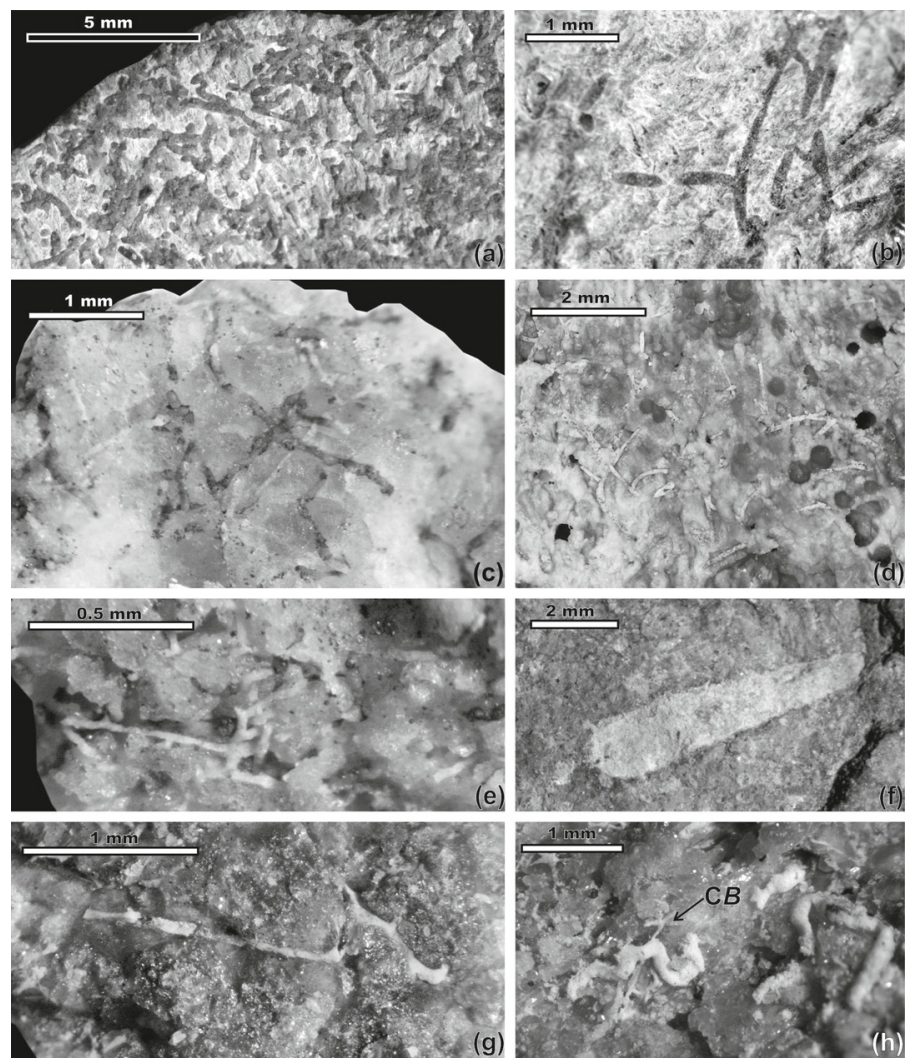

Fig. 12 Other borings in brachiopod shells. (a) Cf. Conchotrema isp. A. (b) Pinaceocladichnus isp. (c) Cf. Conchotrema isp. B. (d) ?Talpina isp. B. (e) Cf. Conchotrema isp. B. (f) Palaeosabella prisca. (g) cf. Conchotrema isp. B. (h) Contorted tubes and cf. Conchotrema isp. B. (CB). 

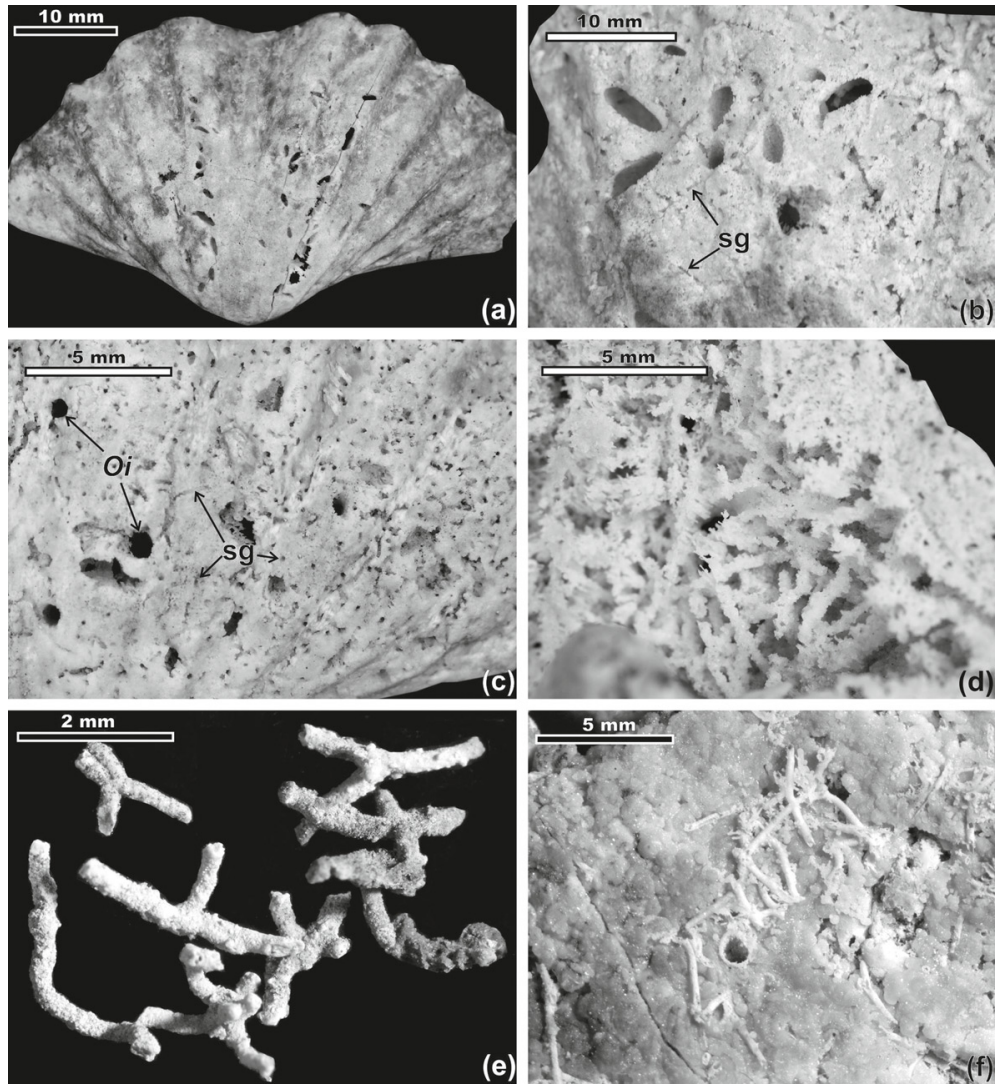

Fig. 13 Borings in brachiopod shells. (a) Rogerella isp. in pedicle valve of spiriferid brachiopod. (b) Rogerella isp. and small galleries (sg). (c) Cf. Oichnus $(\mathrm{Oi})$ and small galleries (sg) marked by small tunnels and holes. (d) ?Talpina isp. A on the inner side of the valve. (e) cf. Conchotrema isp. A. (f) ?Talpina isp. A.

the timing of the onset of sulphidic conditions. Nielsen et al. (2010) showed that sulphidic conditions in water columns gradually became established above the extinction event in the East Greenland Basin, followed by a delayed biotic recovery. At Marmierfjellet, trace fossils recorded from approximately the $372 \mathrm{~m}$ level (Fig. 4) indicate that the infauna recovered somewhat. The bioturbation shut down and the biotic recovery was possibly delayed by episodic shoaling of deep anoxic/ sulphidic waters. This is also evident from the latest Permian mass extinctions of the Meishan section in China (Shen, Crowley et al. 2011; Shen, Farkukar et al. 2011), in south Tibet and British Colombia (Wignall \& Newton 2003), and other areas worldwide (e.g., Hallam 1995).

\section{Mode of deposition and remarks on palaeoecology}

The dominance of pascichnia and fodinichnia in the Kapp Starostin Formation points to an abundance of food in the sediment. In most beds, Nereites cross-cuts Phycosiphon (Fig. 7d), and both of them are cross-cut by
Chondrites, which is rare, however. Phycosiphon is also cross-cut by Zoophycos (Fig. 8c). The situation is similar to the sequential colonization of turbiditic beds (Wetzel $\delta$ Uchman 2001). According to this model, pore water of turbiditic beds contains dissolved oxygen and sediments are rich in organic material. At the beginning, such beds are colonized by the Phycosiphon tracemakers, which are small opportunistic deposit feeders. Later, Phycosiphon is replaced by Nereites, produced by a larger sedimentfeeder. The tracemakers of Phycosiphon and Nereites benefit from the oxygenated pore waters and penetrate the sediment without necessity of connection to the sea floor. Decreasing content of oxygen and food makes horizontal mining difficult. Therefore, the sediment is colonized by producers of Chondrites, produced by stationary chemosymbionts. It may be the case that the role of turbidity currents were played by storm generated currents in the studied section. Only thicker tempestites are not obliterated by bioturbation. Therefore, the storm deposition seems to be underestimated in the sedimentary record. The rarity of Chondrites can be explained by relatively good oxygenation and continuous abundance 


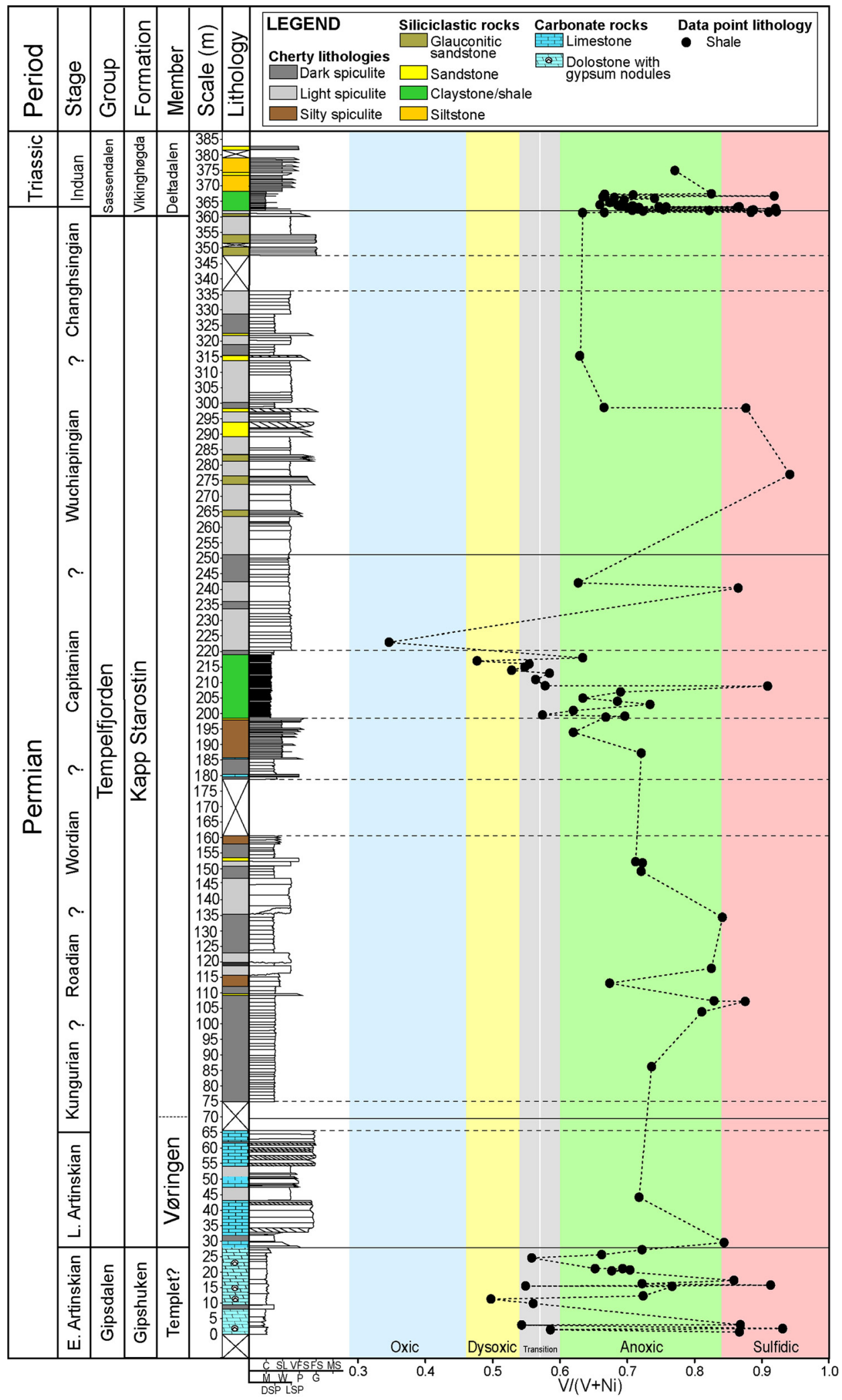

Fig. 14 Sedimentological log for the Marmierfjellet section. Interpretation of anoxicity is expressed as $\mathrm{V} /(\mathrm{V}+\mathrm{Ni})$ ratio of shales differentiating between oxic, dysoxic, anoxic and sulphidic bottom-water conditions during deposition. 


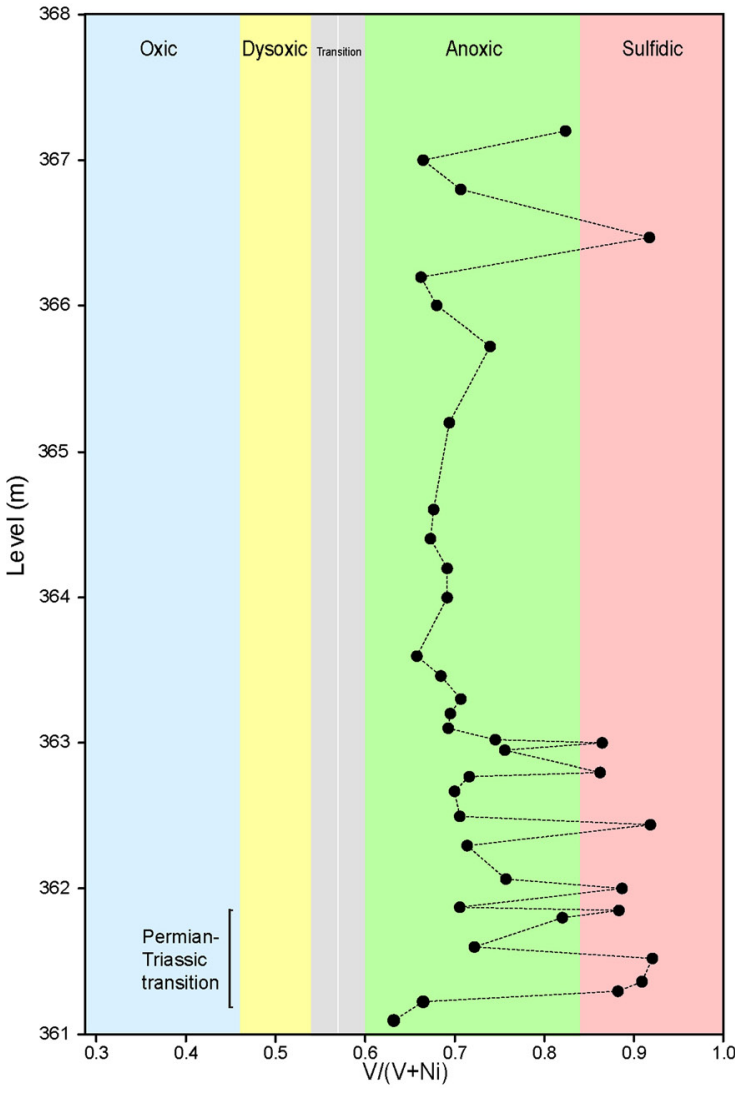

Fig. 15 A close-up of the element ratio $\mathrm{V} /(\mathrm{V}+\mathrm{Ni})$ ratio of shales for the Permian-Triassic transition at the Marmierfjellet. At the PermianTriassic transition, the bottom water fluctuated between anoxic and sulphidic conditions followed by more stable anoxic conditions.

of food, where the Nereites tracemaker was active for a long time. It is probable that horizontal, permanent reworking of sediment by Nereites prevented the development of delicate, vertical Chondrites. The role of Chondrites was played to some extent by Zoophycos, which was able to penetrate deeper beyond the range of Nereites. On some parts of the section, Nereites and Phycosiphon tend to concentrate in thin layers separated by less continuously reworked thicker layers (Fig. 11b), which could have developed at the top of storm beds. In some layers, Nereites is plastically deformed (Fig. 11c); it was probably produced in semi-fluid (soupy) sediment.

Thicker tempestites in the Vøringen Member contain typical storm suites of trace fossils represented by Arenicolites, produced by filter feeders brought in by storm currents. Nereites, Phycosiphon and Zoophycos represent the background ichnofauna which was active between storm events (e.g., Frey \& Goldring 1992; Pemberton et al. 1992; Pemberton \& MacEachern 1997; and references therein).

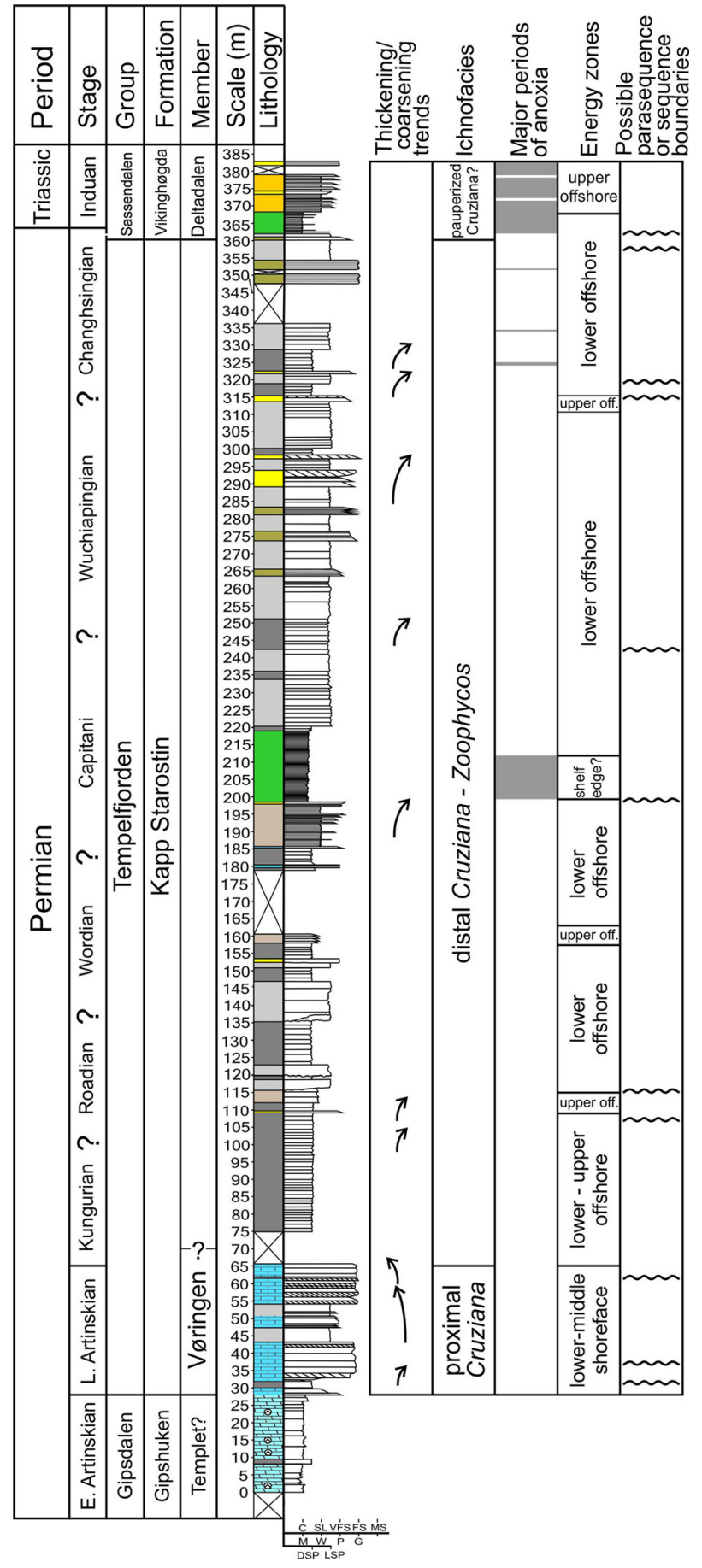

Fig. 16 Main sedimentological and ichnofacies interpretation of subenvironments, oxygenation and sequence/parasequence boundaries. See legend in Fig. 4.

\section{Acknowledgements}

Fieldwork in Svalbard was funded by the Norwegian Research Council and the University of Tromsø (NMH). 
AU received additional support from the Jagiellonian University (DS funds). SAG received funding from the Arctic Petroleum Exploration project (Research Centre for Arctic Petroleum Exploration) which is funded by the Research Council of Norway (grant no. 228107). We gratefully thank Jan Kresten Nielsen for fruitful discussions and Jan Ove Ebbestad for commenting on an earlier draft of the manuscript. Some of the figures were drawn by Jan Petter Holm. We are indebted to Kenneth Andre Evison and Nils Andreas Hanken for field assistance. The paper benefitted from critical review by Francisco Javier Rodríguez-Tovar (Granada) and Paul Wignall (Leeds).

\section{References}

Algeo T.J., Shen Y., Zhang T., Lyons T., Bates S., Rowe H. \& Nguyen T.K.T. 2008. Association of ${ }^{34}$ S-depleted pyrite layers with negative carbonate $\delta^{13} \mathrm{C}$ excursions at the Permian-Triassic boundary: evidence for upwelling of sulfidic deep-ocean water masses. Geochemistry, Geophysics, Geosystems 9, Q04025, doi: 10.1029/2007GC001823.

Beauchamp B. \& Desrochers A. 1997. Permian warm- to very cold-water carbonates and cherts in northwest Pangea. In N.P. James \& J.A.D. Clarke (eds.): Cool-water carbonates. Pp. 327-347. Tulsa: Society of Economic Paleontologists and Mineralogists.

Blomeier D., Dustira A., Forke H. \& Scheibner C. 2011. Environmental change in the Early Permian of NE Svalbard: from a warm-water carbonate platform (Gipshuken Formation) to a temperate, mixed siliciclastic-carbonate ramp (Kapp Starostin Formation). Facies 57, 493-523.

Bottjer D.J., Droser M. \& Jablonski D. 1988. Palaeoenvironmental trends in the history of trace fossils. Nature 333, 252-255.

Bromley R.G. 1996. Trace fossils. Biology, taphonomy and applications. London: Chapman and Hall.

Bromley R.G. \& Asgaard U. 1993. Two bioerosion ichnofacies produced by early and late burial associated with sea level change. Geologische Rundschau 82, 176-280.

Bromley R.G. \& D'Alessandro A. 1990. Comparative analysis of bioerosion in deep and shallow water, Pliocene to recent, Mediterranean Sea. Ichnos 1, 43-49.

Bromley R. \& Hanken N.-M. 1992. Late Permian ichnofabrics from Svalbard, Norway. Geoscientist 1(6), 40.

Bromley R.G., Hanken N.-M., Asgaard U., Fredriksen K.-R. \& Henriksen L.B. 1989. Shallow-water Zoophycos assemblages, Upper Permian, Svalbard. In: Abstracts: 28th International Geological Congress, Washington, D.C. USA, July 9-19, 1989. Vol. 1. Pp. 204-205. Washington, DC: International Geology Congress.

Burgess S.D., Bowring S. \& Shen Shu-zhong. 2014. Highprecision timeline for Earth's most severe extinction. Proceedings of the National Academy of Sciences of the United States of America 111, 3316-3321.

Chen B., Joachimski M.M., Shen S.-Z, Lambert L.L., Lai X.-L., Wang X.-D., Chen J. \& Yuan D.-X. 2013. Permian ice volume and palaeoclimate history: oxygen isotope proxies revisited. Gondwana Research 24, 77-89.

Chen Z.-Q., Fraiser M.L. \& Bolton C. 2012. Early Triassic trace fossils from Gondwana Interior Sea: implication for ecosystem recovery following the end-Permian mass extinction in south high-latitude region. Gondwana Research 22, 238-255.

Chen Z.-Q., Tong J. \& Fraiser M.L. 2011. Trace fossil evidence for restoration of marine ecosystems following the endPermian mass extinction in the Lower Yangtze region, South China. Palaeogeography, Palaeoclimatology, Palaeoecology299, 449-474.

Clifton H.E. \& Thompson J.K. 1978. Macaronichnus segregatis: a feeding structure of shallow marine polychaetes. Journal of Sedimentary Petrology 48, 1293-1302.

Cutbill J.I. \& Challinor A. 1965. Revision of the stratigraphical scheme for the Carboniferous and Permian rocks of Spitsbergen and Bjørnøya. Geological Magazine 102, 418-439. Dallmann W.K., Gjelberg J.G., Harland W.B., Johannessen E.P., Keilen H.B., Lønøy A., Nilsson I. \& Worsley D. 1999. Upper Palaeozoic lithostratigraphy. In W.K. Dallmann (ed.): Lithostratigraphic lexicon of Svalbard. Upper Palaeozoic to Quaternary bedrock. Review and recommendations for nomenclature use. Pp. 25-126. Tromsø: Norwegian Polar Institute.

Dorning K.J., Jacobsen R.A. \& Worsley D. 1984. Permian palynology of Svalbard. Report 04.6361.00/02/84. Trondheim: Continental Shelf Institute.

Dunham R.J. 1962. Classification of carbonate rocks according to their depositional texture. In W.E. Ham (ed.): Classification of carbonate rocks. Pp. 108-121. Tulsa: American Association of Petroleum Geologists.

Dustira A., Wignall P.B., Joachimski M., Blomeier D., Hartkopf-Fröder C. \& Bond D.P.G. 2013. Gradual onset of anoxia across the Permian-Triassic boundary in Svalbard, Norway. Palaeogeography, Palaeoclimatology, Palaeoecology 374, 303-313.

Ehrenberg S.N., Pickard N.A.H., Henriksen L.B., Svånå T.A., Gutteridge P. \& McDonald D. 2001. A depositional and sequence stratigraphic model for coldwater, spiculitic strata based on the Kapp Starostin Formation (Permian) of Spitsbergen and equivalent deposits from the Barents Sea. AAPG Bulletin 85, 2061-2087.

Erwin D.H. 1993. The great Paleozoic crisis. Life and death in the Permian. New York: Columbia University Press.

Erwin D.H. 2006. Extinction! How life nearly ended 250 million years ago. Princeton, NJ: Princeton University Press.

Ezaki Y., Kawamura T. \& Nakamura K. 1994. Kapp Starostin Formation in Spitsbergen: a sedimentary and faunal record of Late Permian palaeoenvironments in an Arctic region. In A.F. Embry et al. (eds.): Pangea: global environments and resources. Pp. 647-655. Calgary: Canadian Society of Petroleum Geologists.

Fischer-Ooster C. 1858. Die Fossilen Fucoiden der SchweizerAlpen, nebst Erörterungen über deren geologisches Alter. (The fossil fucoids of the Swiss Alps along with arguments concerning their geological age) Bern: Huber.

Fredriksen K.R. 1988. Sedimentologiske og diagenetiske undersøkelser av Kapp Starostinformasjonen på Akseløya og Mariaholmen, 
Bellsund, Svalbard. (Sedimentological and diagenetic investigations of the Kapp Starostin Formation at Akseloya and Mariaholmen, Bellsund, Svalbard.) Cand. scient. thesis, Department of Geology, University of Tromsø.

Frey R.W., Curran A.H. \& Pemberton G.S. 1984. Trace making activities of crabs and their environmental significance: the ichnogenus Psilonichnus. Journal of Paleontology 58, 333-350.

Frey R.W. \& Goldring R. 1992. Marine event beds and recolonization surfaces as revealed by trace fossil analysis. Geological Magazine 129, 325-335.

Frey R.W. \& Seilacher A. 1980. University in marine invertebrate ichnology. Lethaia 13, 183-207.

Georgieva S., Stein H.J., Hannah J.L., Bingen B., Weiss H.M. \& Piasecki S. 2011. Hot acidic Late Permian seas stifle life in record time. Earth and Planetary Science Letters 310, 389-400.

Golonka J. 2011. Phanerozoic palaeoenvironment and palaeolithofacies maps of the Arctic region. In A.M. Spencer et al. (eds.): Arctic petroleum geology. Pp. 79-129. London: Geological Society.

Gradstein F.M., Ogg J.G., Schmitz M. \& Ogg G. 2012. The geologic time scale 2012. Amsterdam: Elsevier.

Grundvåg S.-A. 2008. Facies analysis, sequence stratigraphy and geochemistry of the middle-upper Permian Kapp Starostin Formation, central Spitsbergen. MSc thesis, Department of Geology, University of Tromsø.

Grundvåg S.-A., Hanken N.-M., Nielsen J. K. \& Uchman A. 2013. Depositional evolution of a mixed carbonatespiculite-siliciclastic platform: facies analysis and sequence stratigraphy of the Permian-Triassic succession, central Spitsbergen. In D. Bond \& D. Blomeier (eds.): The Permian strata of Svalbard. Norwegian Polar Institute, Tromsø, April 10-12, 2013. Abstracts and proceedings. Pp. 16-17. Tromsø: Norwegian Polar Institute.

Gruszczyński M., Hałas S., Hoffman A. \& Małkowski K. 1989. A brachiopod calcite record of the oceanic carbon and oxygen isotope shifts at the Permian/Triassic transition. Nature 337, 64-68.

Hall J. 1847. Palaeontology of New-York. Vol. 1. Albany: C. Van Benthuysen.

Hallam A. 1995. The earliest Triassic as an anoxic event, and its relationship to the end-Palaeozoic mass extinction. Canadian Society of Petroleum Geologists Memoir 17, 797-804.

Hanken N.-M., Bromley R.G., Asgaard U., Fredriksen K.-R., Henriksen L.B. \& Espenes H.J. 1989. Underkambriske og overpermiske sporfossilassosiasjoner fra Nord-Norge og Svalbard. (Lower Cambrian and Upper Permian trace fossil assemblages from North Norway and Svalbard.) Contribution from the Paleontological Museum. University of Oslo 359, 13-14.

Harland W.B., Anderson L.M. \& Manasrah D. 1997. The geology of Svalbard. London: Geological Society.

Henriksen L.B. 1988. En sedimentologisk og diagenetisk undersøkelsae av Kapp Starostinformasjonen pa Akseløya og Mariaholmen, Svalbard. (A sedimentological and diagenetic investigation of the Kapp Starostin Formation at Akseloya and Mariaholmen, Svalbard.) Cand. scient. thesis, Department of Geology, University of Tromsø.
Hofmann R., Goudemand N., Wasmer M., Bucher H. \& Hautmann M. 2011. New trace fossil evidence for an early recovery signal in the aftermath of the end-Permian mass extinction. Palaeogeography, Palaeoclimatology, Palaeoecology 310, 216-226.

Hounslow M.W., Mørk A., Peters C. \& Weitschat W. 1996. Boreal Lower Triassic magnetostratigraphy from Deltadalen, central Svalbard. Albertiana 17, 3-10.

Hounslow M.W. \& Nawrocki J. 2008. Palaeomagnetism and magnetostratigraphy of the Permian and Triassic of Spitsbergen: a review of progress and challenges. Polar Research 27, 502-522.

Hounslow M.W., Peters C., Mørk A., Weitschat W. \& Vigran J.O. 2008. Biomagnetostratigraphy of the Vikinghøgda Formation, Svalbard (Arctic Norway), and the geomagnetic polarity timescale for the Lower Triassic. Geological Society of America Bulletin 120, 1305-1325.

Hüneke H., Joachimski M., Buggisch W. \& Lützner H. 2001. Marine carbonate facies in response to climate and nutrient level: the Upper Carboniferous and Permian of central Spitsbergen (Svalbard). Facies 45, 93-136.

Jin Y.G., Wang Y., Wang W., Shang Q.H., Cao C.Q. \& Erwin D.H. 2000. Pattern of marine mass extinction near the Permian-Triassic boundary in south China. Science 289, 432-436.

Kajiwara Y., Yamakita S., Ishida K., Ishiga H. \& Imai A. 1994. Development of a largely anoxic stratified ocean and its temporary massive mixing at the Permian-Triassic boundary supported by the sulfur isotopic record. Palaeogeography, Palaeoclimatology, Palaeoecology 111, 367-379.

Knoll A.H. 2004. Biomineralization and evolutionary history. In P.M. Dove et al. (eds.): Reviews in mineralogy and geochemistry 54, 329-356.

Knoll A.H., Bambach R.K., Payne J.L., Pruss S. \& Fischer W.W. 2007. Paleophysiology and end-Permian mass extinction. Earth and Planetary Science Letters 256, 295-313.

Lofek M. 2012. Skamieniałości śladowe z utworów permu i triasu wysp Akseløya i Mariaholmen, Svalbard Zachodni (Trace fossils from the Permian and Triassic sediments at Akseloya and Mariaholmen, west Svalbard.) MSc thesis, Institute of Geological Sciences, Jagiellonian University, Kraków.

MacEachern J.A., Pemberton S.G., Gingras M.K. \& Bann K.L. 2007. The ichnofacies paradigm: a fifty-year retrospective. In W. Miller III (ed.): Trace fossils. Concepts, problems, prospects. Pp. 52-77. Amsterdam: Elsevier.

MacNaughton R.B. \& Zonneveld J.-P. 2010. Trace-fossil assemblages in the Lower Triassic Toad Formation, La Biche River map area, southeastern Yukon. Bulletin of Canadian Petroleum Geology 58, 100-114.

Major H., Nagy J., Haremo P., Dallmann W.K., Andresen A. \& Salvigsen O. 1992. Geological Map of Svalbard 1:100 000. Sheet C9G Adventdalen. Oslo: Norwegian Polar Institute.

Małkowski K. 1982. Development and stratigraphy of the Kapp Starostin Formation (Permian) of Spitsbergen. In G. Biernat \& W. Szymańska (eds.): Palaeontological Spitsbergen 
studies. Part 1. Paleontologica Polonica 43. Pp. 69-81. Warsaw: National Scientific Publishers.

Małkowski K. 1988. Paleoecology of Productacea (Brachiopoda) from the Permian Kapp Starostin Formation, Spitsbergen. Polish Polar Research 9, 3-60.

Małkowski K., Gruszczyński M., Hoffman A. \& Hałas S. 1989. Oceanic stable isotope composition and a scenario for the Permo-Triassic crisis. Historical Biology 2, 289-309.

Małkowski K. \& Hoffman A. 1979. Semi-quantitative facies model for the Kapp Starostin Formation (Permian), Spitsbergen. Acta Geologica Polonica 24, 217-233.

Mangerud G. 1994. Palynostratigraphy of the Permian and lowermost Triassic succession, Finnmark Platform, Barents Sea. Review of Palaeobotany and Palynology 82, 317-349.

Mangerud G. \& Konieczny R.M. 1993. Palynology of the Permian succession of Spitsbergen, Svalbard. Polar Research $12,65-93$.

Mørk A., Elvebakk G., Forsberg A.W., Hounslow M.W., Nakrem H.A., Vigran J.O. \& Weistchat W. 1999. The type section of the Vikinghøgda Formation: a new Lower Triassic unit in central and eastern Svalbard. Polar Research 18, 51-82.

Mørk A., Embry A.F. \& Weitschat W. 1989. Triassic transgressiveregressive cycles in the Sverdrup Basin and the Barents Sea. In J.D. Collinson (ed.): Correlation in hydrocarbon exploration. Pp. 113-130. London: Graham \& Trotman Ltd.

Mørk A., Knarud R. \& Worsley D. 1982. Depositional and diagenetic environments of the Triassic and lower Jurassic of Svalbard. Memoir of the Canadian Society of Petroleum Geologists 8, 371-398.

Mørk A. \& Mangerud G. 2013. The Permian-Triassic transition on Svalbard and in the Barents Sea. In D. Bond $\&$ D. Blomeier (eds.): The Permian strata of Svalbard. Norwegian Polar Institute, Tromsø, April 10-12, 2013. Abstracts and proceedings. Pp. 18-19. Tromsø: Norwegian Polar Institute.

Nabbefeld B., Grice K., Twitchett R.J., Summons R.E., Hays L., Böttcher M.E. \& Asif M. 2010. An integrated biomarker, isotopic and palaeoenvironmental study through the Late Permian event at Lusitaniadalen, Spitsbergen. Earth and Planetary Science Letters 291, 84-96.

Nakrem H.A. 1994. Environmental distribution of bryozoans in the Permian of Spitsbergen. In P.J. Hayward et al. (eds.): Biology and palaeobiology of bryozoans. Pp. 133-137. Fredensborg, Denmark: Olsen \& Olsen.

Nakrem H.A., Nilsson I. \& Mangerud G. 1992. Permian biostratigraphy of Svalbard (Arctic Norway)-a review. International Geology Review 34, 933-959.

Nielsen J.K., Błażejowski B., Gieszcz P. \& Nielsen J.K. 2013. Carbon and oxygen isotope records of Permian brachiopods from relatively low and high palaeolatitudes: climatic seasonality and evaporation. In A. Gąsiewicz \& M. Słowakiewicz (eds.): Palaeozoic climate cycles: their evolutionary and sedimentological impact. Pp. 387-406. London: Geological Society.

Nielsen J.K. \& Shen Y. 2004. Evidence for sulfidic deep water during the Late Permian in the East Greenland Basin. Geology 32, 1037-1040.
Nielsen J.K., Shen Y., Piasecki S. \& Stemmerik L. 2010. No abrupt change in redox condition caused the end-Permian marine ecosystem collapse in the East Greenland Basin. Earth and Planetary Science Letters 291, 32-38.

Olempska E. \& Błaszyk J. 1996. Ostracods from Permian of Spitsbergen. Polish Polar Research 17, 3-20.

Olivero D. 2003. Early Jurassic to Late Cretaceous evolution of Zoophycos in French Subalpine Basin (southeast France). Palaeogeography, Palaeoclimatology, Palaeoecology 192, 59-78.

Payne J.L. \& Clapham M.E. 2012. End-Permian mass extinction in the oceans: an ancient analog for the twenty-first century? Annual Review of Earth and Planetary Science 40, 89-111.

Payne J.L., Lehrmann D.J., Follett D., Seibel M., Kump L.R., Riccardi A., Altiner D., Sano H. \& Wei J. 2007. Erosional truncation of uppermost Permian shallow-marine carbonates and implications for Permian-Triassic boundary events. Geological Society of America Bulletin 119, 771-784.

Pemberton G.S., Spila M., Pulham A.J., Saunders T., MacEachern J.A., Robbins D. \& Sinclair I.K. 2001. Ichnology and sedimentology of shallow to marginal marine systems: Ben Nevis and Avalon reservoirs, Jeanne D'Arc Basin. Short Course Notes 15. St. John's, Newfoundland: Geological Association of Canada.

Pemberton S.G. \& MacEachern J.A. 1997. The ichnological signature of storm deposits: the use of trace fossils in event stratigraphy. In C.E. Brett \& G.C. Baird (eds.): Paleontological events, stratigraphical, ecological and evolutionary implications. Pp. 73-109. New York: Columbia University Press.

Pemberton S.G., MacEachern J.A. \& Ranger M.J. 1992. Ichnology and event stratigraphy: the use of trace fossils in recognizing tempestites. In S.G Pemberton (ed.): Applications of ichnology to petroleum exploration. A core workshop. Pp. 85-117. Tulsa: Society of Economic Paleontologists and Mineralogists.

Rieth A. 1932. Neue Funde spongeliomorpher Fucoiden aus dem Jura Schwabens. (New discoveries of spongeliomorph fucoids from the Jurassic of Swabia.) Geologische und Paläontogische Abhandlungen, N.F. 19, 257-294.

Sahney S. \& Benton M.J. 2008. Recovery from the most profound mass extinction of all time. Proceedings of the Royal Society B 275, 759-765.

Schoepfer S.D., Henderson C.M., Garrison G.H., Foriel J., Ward P.D., Selby D., Hower J.C., Algeo T.J. \& Shen Y. 2013. Termination of a continent-margin upwelling system at the Permian-Triassic boundary (Opal Creek, Alberta, Canada). Global and Planetary Change 105, 21-35.

Shen S.Z., Crowley J.L., Wang Y., Bowring S.A., Erwin D.H., Sadler P.M., Cao C.Q., Rothman D.H., Henderson C.M., Ramezani J., Zhang H., Shen Y., Wang X.D., Wang W., Mu L., Li W.Z., Tang Y.G., Liu X.L., Liu L.J., Zeng Y., Jiang Y.F. \& Jin Y.G. 2011 . Calibrating the end-Permian mass extinction. Science 334, 1367-1372.

Shen Y., Farquhar J., Zhang H., Masterson A., Zhang T. \& Wing B.A. 2011. Multiple S-isotopic evidence for episodic shoaling of anoxic water during Late Permian mass extinction. 
Nature Communications 2, article no. 210, doi: 10.1038/ ncomms 1217

Steel R.J. \& Worsley D. 1984. Svalbard's post-Caledonian strata - an atlas of sedimentational patterns and palaeogeographic evolution. In A.M. Spencer (ed.): Petroleum geology of the North European margin. Pp. 109-135. London: Graham \& Trotman Ltd.

Stemmerik L. 1997. Permian (Artinskian-Kazanian) coolwater carbonates in North Greenland, Svalbard and the western Barents Sea. In N.P. James \& J.A.D. Clarke (eds.): Cool-water carbonates. Pp. 349-364. Tulsa: Society of Economic Paleontologists and Mineralogists.

Stemmerik L. 2000. Late Palaeozoic evolution of the North Atlantic margin of Pangea. Palaeogeography, Palaeoclimatology, Palaeoecology 161, 95-126.

Stemmerik L. \& Worsley D. 1995. Permian history of the Barents Shelf area. In P.A. Scholle et al. (eds.): The Permian of northern Pangea. Vol. 2. Sedimentary basins and economic resources. Pp. 81-97. Berlin: Springer.

Stemmerik L. \& Worsley D. 2005. 30 years on: Arctic Upper Palaeozoic stratigraphy, depositional evolution and hydrocarbon prospectivity. Norwegian Journal of Geology 85, 151-168.

Sun Y., Joachimski M.M., Wignall P.B., Yan C., Chen Y., Jiang H., Wangm L. \& Laim X. 2012. Lethally hot temperatures during the Early Triassic greenhouse. Science 338, 366-370.

Szaniawski H. \& Małkowski K. 1979. Conodonts from the Kapp Starostin Formation (Permian) of Spitsbergen. Acta Palaeontologica Polonica 24, 231-264.

Twitchett R.J. 2006. The palaeoclimatology, palaeoecology and palaeoenvironmental analysis of mass extinction events. Palaeogeography, Palaeoclimatology, Palaeoecology 232, 190-213.

Twitchett R.J., Looy C.V., Morante R., Visscher H. \& Wignall P.B. 2001. Rapid and synchronous collapse of marine and terrestrial ecosystems during the end-Permian biotic crisis. Geology 29, 351-354.

Twitchett R.J. \& Wignall P.B. 1996. Trace fossils and the aftermath of the Permo-Triassic mass extinction: evidence from northern Italy. Palaeogeography, Palaeoclimatology, Palaeoecology 124, 137-151.
Vigran J.O., Mangerud G., Mørk A., Worsley D. \& Hochuli P. 2014. Palynology and geology of the Triassic succession of Svalbard and the Barents Sea. Trondheim: Geological Survey of Norway.

Visscher H., Brinkhuis H., Dilcher D.L., Elsik W.C., Eshet Y., Looy C.V., Rampino M.R. \& Traverse A. 1996. The terminal Paleozoic fungal event: evidence of terrestrial ecosystem destabilization and collapse. Proceedings of the National Academy of Sciences of the United States of America 93, 2155-2158.

Wei H., Algeo T.J., Yu H., Wang J., Guo C. \& Shi G. 2015. Episodic euxinia in the Changhsingian (late Permian) of south China: evidence from framboidal pyrite and geochemical data. Sedimentary Geology 319, 78-97.

Weller S. 1889. Kinderhook faunal studies. I. The fauna of the vermicular sandstone at Northview, Webster County, Missouri. Transactions of the Academy of Science of St. Louis 9, 9-51.

Wetzel A. \& Uchman A. 2001. Sequential colonization of muddy turbidites: examples from Eocene Beloveža Formation, Carpathians, Poland. Palaeogeography, Palaeoclimatology, Palaeoecology 168, 171-186.

Wignall P., Bond D. \& Blomeier D. 2013. The Kapp Starostin Formation: a record of the Late Permian mass extinction or no Late Permian record at all? In D. Bond \& D. Blomeier (eds.): The Permian strata of Svalbard. Norwegian Polar Institute, Tromsø, April 10-12, 2013. Abstracts and proceedings. P. 23. Tromsø: Norwegian Polar Institute.

Wignall P.B., Morante R. \& Newton R. 1998. The PermoTriassic transition in Spitsbergen: $\delta^{13} \mathrm{C}_{\text {org }}$ chemostratigraphy, $\mathrm{Fe}$ and $\mathrm{S}$ geochemistry, facies, fauna and trace fossils. Geological Magazine 135, 47-62.

Wignall P.B. \& Newton R. 2003. Contrasting deep-water records from the Upper Permian and Lower Triassic of south Tibet and British Columbia: evidence for a diachronous mass extinction. Palaios 18, 153-167.

Wignall P.B. \& Twitchett R.J. 1996. Oceanic anoxia and the end Permian mass extinction. Science 272, 1155-1158.

Worsley D., Aga O.J., Dalland A., Elverhøy A. \& Thon A. 1986. The geological history of Svalbard: evolution of an archipelago. Stavanger: Statoil. 